\title{
The effect of meteorological and chemical factors on the agreement between observations and predictions of fine aerosol composition in southwestern Ontario during BAQS-Met
}

\author{
M. Z. Markovic ${ }^{1}$, K. L. Hayden ${ }^{2}$, J. G. Murphy ${ }^{1}$, P. A. Makar ${ }^{2}$, R. A. Ellis ${ }^{1}$, R. Y.-W. Chang ${ }^{1}$, J. G. Slowik ${ }^{1, *}$, \\ C. Mihele ${ }^{2}$, and J. Brook ${ }^{2}$ \\ ${ }^{1}$ Department of Chemistry, University of Toronto, Toronto, Ontario, Canada \\ ${ }^{2}$ Air Quality Research Division, Environment Canada, Toronto, Ontario, Canada \\ *now at Paul Scherrer Institut, 5232 Villigen PSI, Switzerland
}

Received: 13 September 2010 - Published in Atmos. Chem. Phys. Discuss.: 22 October 2010

Revised: 8 March 2011 - Accepted: 21 March 2011 - Published: 5 April 2011

\begin{abstract}
The Border Air Quality and Meteorology Study (BAQS-Met) was an intensive, collaborative field campaign during the summer of 2007 that investigated the effects of transboundary pollution, local pollution, and local meteorology on air quality in southwestern Ontario. This analysis focuses on the measurements of the inorganic constituents of particulate matter with diameter of less than $1 \mu \mathrm{m}\left(\mathrm{PM}_{1}\right)$, with a specific emphasis on nitrate. We evaluate the ability of AURAMS, Environment Canada's chemical transport model, to represent regional air pollution in SW Ontario by comparing modelled aerosol inorganic chemical composition with measurements from Aerosol Mass Spectrometers (AMS) onboard the National Research Council (NRC) of Canada Twin Otter aircraft and at a ground site in Harrow, $\mathrm{ON}$. The agreement between modelled and measured $p \mathrm{NO}_{3}^{-}$ at the ground site (observed mean $\left(\mathrm{M}_{\mathrm{obs}}\right)=0.50 \mu \mathrm{g} \mathrm{m}^{-3}$; modelled mean $\left(\mathrm{M}_{\text {mod }}\right)=0.58 \mu \mathrm{g} \mathrm{m}^{-3}$; root mean square error $\left.(\mathrm{RSME})=1.27 \mu \mathrm{g} \mathrm{m}^{-3}\right)$ was better than aloft $\left(\mathrm{M}_{\mathrm{obs}}\right.$ $\left.=0.32 \mu \mathrm{g} \mathrm{m}^{-3} ; \mathrm{M}_{\text {mod }}=0.09 \mu \mathrm{g} \mathrm{m}^{-3} ; \mathrm{RSME}=0.48 \mu \mathrm{g} \mathrm{m}^{-3}\right)$. Possible reasons for discrepancies include errors in (i) emission inventories, (ii) atmospheric chemistry, (iii) predicted meteorological parameters, or (iv) gas/particle thermodynamics in the model framework. Using the inorganic thermodynamics model, ISORROPIA, in an offline mode, we find that the assumption of thermodynamic equilibrium is consistent with observations of gas and particle composition at Harrow. We develop a framework to assess the sensitivity of $\mathrm{PM}_{1}$ nitrate to meteorological and chemical parameters and find that errors in both the predictions of relative humidity
\end{abstract}

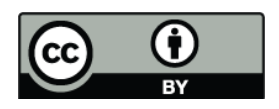

Correspondence to: J. G. Murphy (jmurphy@chem.utoronto.ca) and free ammonia $\left(\mathrm{FA} \equiv \mathrm{NH}_{3(\mathrm{~g})}+p \mathrm{NH}_{4}^{+-}-2 \cdot p \mathrm{SO}_{4}^{2-}\right)$ are responsible for the poor agreement between modelled and measured values.

\section{Introduction}

Atmospheric $\mathrm{PM}_{1}$ refers to liquid and solid particles suspended in air with aerodynamic diameters of less than $1 \mu \mathrm{m}$. They are ubiquitous in the atmosphere and are important because they alter the radiative balance of the Earth either by scattering incoming solar radiation directly, or by serving as cloud condensation nuclei $(\mathrm{CCN})$ in cloud formation. $\mathrm{PM}_{1}$ also reduces visibility through the formation of haze, affects sensitive ecosystems through acid deposition, and provides surface area for several important atmospheric chemical reactions (Seinfeld, 1996; Jacob, 1999; Finlayson-Pitts and Pitts, 2000; Pinder et al., 2007). Recent studies have linked $\mathrm{PM}_{1}$ to pulmonary disease and reduced lung function (Oberdorster, 2001; Gauderman et al., 2004), cardiac arrest (Dockery, 2001; Peters et al., 2001; Dominici et al., 2006) and in some cases even premature death (Burnett et al., 2000; Pope et al., 2002). For these reasons understanding the processes that govern the sources, sinks and chemical composition of $\mathrm{PM}_{1}$ is of utmost importance.

In Eastern North America, more than 50\% of the composition of atmospheric fine particulate matter is inorganic in nature, containing mostly sulphate $\left(\mathrm{SO}_{4}^{2-}\right)$, ammonium $\left(\mathrm{NH}_{4}^{+}\right)$ and nitrate $\left(\mathrm{NO}_{3}^{-}\right)$(Jacob, 1999; Pinder et al., 2007). These constituents of inorganic $\mathrm{PM}_{1}$ are secondary in nature and are formed by physical processes (e.g. condensation) or chemical reactions of precursor gases such as $\mathrm{H}_{2} \mathrm{SO}_{4(\mathrm{~g})}, \mathrm{HNO}_{3(\mathrm{~g})}$

Published by Copernicus Publications on behalf of the European Geosciences Union. 
and $\mathrm{NH}_{3(\mathrm{~g})}$. Sulphuric and nitric acid are atmospheric oxidation products of the gases $\mathrm{SO}_{2}$ and $\mathrm{NO}_{\mathrm{x}}\left(\equiv \mathrm{NO}+\mathrm{NO}_{2}\right)$ respectively, and $\mathrm{NH}_{3(\mathrm{~g})}$ is directly emitted into the atmosphere mainly from agricultural sources, although in urban areas other sources such as motor vehicles and human waste are non-trivial (Seinfeld, 1996; Jacob, 1999; Finlayson-Pitts and Pitts, 2000; Pinder et al., 2007).

The secondary formation of inorganic $\mathrm{PM}_{1}$ is governed by thermodynamics. Once formed, $\mathrm{H}_{2} \mathrm{SO}_{4}$ will remain in the condensed (particle) phase due to its low vapour pressure. $\mathrm{NH}_{3(\mathrm{~g})}$ will react preferentially with $\mathrm{H}_{2} \mathrm{SO}_{4(\mathrm{aq}, \mathrm{s})}$ to neutralize it even in the presence of significant $\mathrm{HNO}_{3(\mathrm{~g})}$. Up to 2 moles of $\mathrm{NH}_{3(\mathrm{~g})}$ will react with $\mathrm{H}_{2} \mathrm{SO}_{4(\mathrm{aq}, \mathrm{s})}$ to form particulate ammonium sulphate (Stelson and Seinfeld, 1982; Seinfeld, 1996).

Depending on the ambient temperature $(T)$, relative humidity ( $\mathrm{RH})$ and the amounts of each species, semivolatile $\mathrm{HNO}_{3}$ and $\mathrm{NH}_{3}$ can partition between the gas and particle phases in order to establish a thermodynamic equilibrium $\left(\mathrm{HNO}_{3(\mathrm{~g})} \leftrightarrow \mathrm{NO}_{3}^{-}(\mathrm{aq}, \mathrm{s}) ; \mathrm{NH}_{3(\mathrm{~g})} \leftrightarrow \mathrm{NH}_{4}^{+}(\mathrm{aq}, \mathrm{s})\right.$ ). The formation of $\mathrm{NO}_{3}^{-}$(aq,s) depends strongly on not only $\mathrm{RH}$ and $T$, but also on the absolute amounts and availability of total ammonia ( $\mathrm{TA} \equiv \mathrm{NH}_{3(\mathrm{~g})}+\mathrm{NH}_{4}^{+}(\mathrm{aq}, \mathrm{s})$ ), total sulphate $\left(\mathrm{TS} \equiv \mathrm{H}_{2} \mathrm{SO}_{4(\mathrm{~g})}+\mathrm{HSO}_{4}^{-}(\mathrm{aq}, \mathrm{s})+\mathrm{SO}_{4}^{2-}{ }_{(\mathrm{aq}, \mathrm{s})}=\sim \mathrm{HSO}_{4}^{-}(\mathrm{aq}, \mathrm{s})\right.$ $+\mathrm{SO}_{4}^{2-}(\mathrm{aq}, \mathrm{s})$ ) and total nitrate $\left(\mathrm{TN} \equiv \mathrm{HNO}_{3(\mathrm{~g})}+\mathrm{NO}_{3}^{-}(\mathrm{aq}, \mathrm{s})\right.$ (Seinfeld, 1996).

Only when sulphuric acid is completely neutralized, can the remaining $\mathrm{NH}_{3(\mathrm{~g})}$, if available, react with $\mathrm{HNO}_{3(\mathrm{~g})}$ to form $\mathrm{NH}_{4} \mathrm{NO}_{3(\mathrm{aq}, \mathrm{s})}$. Thermodynamically, the formation of ammonium nitrate, and hence particulate nitrate, is governed by the $\mathrm{NH}_{4} \mathrm{NO}_{3(\mathrm{aq}, \mathrm{s})}$ dissociation constant, $\mathrm{K}_{\mathrm{p}}$ which is related to the product of partial pressures of $\mathrm{NH}_{3(\mathrm{~g})}$ and $\mathrm{HNO}_{3(\mathrm{~g})}$ by the following equation (Stelson and Seinfeld, 1982; Mozurkewich, 1993; Seinfeld, 1996):

$\ln K_{\mathrm{p}}=84.6-(24220 / T)-6.1 \cdot \ln (T / 298.15)$

where $K_{\mathrm{p}}=P_{\mathrm{NH}_{3}} \cdot P_{\mathrm{HNO}_{3}}$

where $T$ is in Kelvin, and $P_{\mathrm{X}}$ is the gas phase partial pressure in ppb. When the aerosol is aqueous, the equilibrium product $\left(K_{\mathrm{p}}^{*}\right)$ depends on the solution concentrations, the Henry's law constants $\left(\mathrm{H}_{\mathrm{x}}\right)$ and activities $\left(\alpha_{\mathrm{x}}\right)$ must be considered (Mozurkewich, 1993; Finlayson-Pitts and Pitts, 2000):

$K_{\mathrm{p}}^{*}=\frac{\alpha_{\mathrm{NH}_{3}} \cdot \alpha_{\mathrm{HNO}_{3}}}{\mathrm{H}_{\mathrm{NH}_{3}} \cdot \mathrm{H}_{\mathrm{HNO}_{3}}}$

In this manuscript, we refer to particulate nitrate as $\mathrm{pNO}_{3}^{-}$, whether in the solid or aqueous form, and similarly particulate ammonium is referred to as $p \mathrm{NH}_{4}^{+}$. The term $\mathrm{pSO}_{4}^{2-}$ refers to the sum of $\mathrm{SO}_{4}^{2-}{ }_{(\mathrm{aq}, \mathrm{s})}$ and $\mathrm{HSO}_{4}^{-}(\mathrm{aq}, \mathrm{s})$, which cannot be distinguished by our measurements.

When meteorological conditions in the atmosphere change, the distribution of the ammonium-sulphate-nitrate system between the gas and particle phases may also change. The change subsequently alters the atmospheric lifetime of some of the constituents. Compared to the gas phase, the dry deposition velocities of ammonium and nitrate in fine particles are much lower, so partitioning to the particle phase results in higher steady state concentrations of atmospheric reactive nitrogen. The compounds can then be transported longer distances downwind of emission sources to remote regions where they can affect fragile ecosystems through acid and nutrient deposition (Seinfeld, 1996; Finlayson-Pitts and Pitts, 2000). As $\mathrm{SO}_{2}$ and $\mathrm{NO}_{\mathrm{x}}$ emissions are decreasing in much of the developed world, it is expected that nitrate will become a more important constituent of inorganic aerosol, both in relative and possibly absolute terms. This will impact the effectiveness of PM precursor emission controls, the spatial distribution of nitrogen deposition, and the rates of many heterogeneous reactions, including e.g. the reactive uptake of $\mathrm{N}_{2} \mathrm{O}_{5}$. To assess the ability of a model to examine these impacts and make predictions, it is important to test its ability to determine $\mathrm{pNO}_{3}^{-}$and its sensitivity to a range of input parameters.

In order to describe the processes that govern the formation and partitioning of particulate matter in the atmosphere, numerous thermodynamic partitioning models have been developed: EQUIL (Bassett and Seinfeld, 1983), KEQUIL (Bassett and Seinfeld, 1984), MARS (Saxena et al., 1986), SEQUILIB (Pilinis and Seinfeld, 1987), AIM (Wexler and Seinfeld, 1990, 1991; Clegg, 1992; Clegg and Pitzer, 1992; Clegg et al., 1992), SCAPE (Kim et al., 1993a, b), EQUISOLV (Jacobson et al., 1996), ISORROPIA (Nenes et al., 1998, 1999) and others. The more recently developed or revised thermodynamic partitioning models include SCAPE 2 (Kim and Seinfeld, 1995; Meng et al., 1995), AIM 2 (Clegg et al., 1998a, b; Wexler and Clegg, 2002), GFEMN (Ansari and Pandis, 1999a, b), EQUISOLV II (Jacobson, 1999), MESA (Zaveri et al., 2005), UHAERO (Amundson et al., 2006), and ISORROPIA II (Fountoukis and Nenes, 2007). These equilibrium partitioning models, which are used to predict the gas/particle partitioning of inorganic semi-volatile species at atmospherically relevant conditions (RH, $T$ ), differ in the type and variety of chemical species that they can treat, the type of input they can accept, the method they use to predict (solve for) the composition at thermodynamic equilibrium, and their computational efficiency (Fountoukis et al., 2009). For these reasons, the outputs of the models differ, and their ability to accurately predict the equilibrium partitioning is usually assessed by comparisons to other models and to measurements assuming that the thermodynamic equilibrium between gases and particles was established on the time scales of the measurements (Ansari and Pandis, 1999a; Zhang et al., 2000, 2003; Moya et al., 2001; Yu et al., 2005; Amundson et al., 2006; Fountoukis and Nenes, 2007). The differences and similarities between outputs of thermodynamic equilibrium models are discussed elsewhere (Ansari and Pandis, 1999a; Zhang et al., 2000; Amundson et al., 2006; Fountoukis and Nenes, 2007). Ansari and Pandis (1999a), and Zhang et 
al. (2000) demonstrated that most of the reviewed equilibrium partitioning models were generally comparable in predictions of particle composition under most atmospherically relevant conditions.

Compared to other thermodynamic partitioning models, ISORROPIA uses a set of unique process-solving mechanisms with nested algorithms that allow it to be more robust and require much less computational time for thermodynamic calculations (Nenes et al., 1998, 1999). The thermodynamic system modelled by ISORROPIA includes TA, TS, TN and water, which are partitioned between gas, liquid and solid phases depending on the meteorological input parameters. During computations, ISORROPIA assumes that all particles have identical chemical composition. Due to its robustness and rapid computations, the model has been embedded in three-dimensional chemical transport models such as A Unified Regional Air Quality Modelling System, AURAMS (Zhang et al., 2002; Makar et al., 2003; Gong et al., 2006), Community Multiscale Air Quality Modelling System, CMAQ (Binkowski and Roselle, 2003; Mebust et al., 2003), and Particulate Matter Comprehensive Air Quality Model with Extensions, PMCAMx (Gaydos et al., 2007; Karydis et al., 2007) in addition to being used offline to model thermodynamic partitioning of the inorganic ammonium-sulphate-nitrate-water system. Several studies have been conducted to test the applicability of thermodynamic equilibrium by comparison of ISORROPIA-calculated gas/particle partitioning to field measurements in Mexico City (Moya et al., 2001; San Martini et al., 2006; Hennigan et al., 2008; Fountoukis et al., 2009; Karydis et al., 2010), Atlanta (Zhang et al., 2003; Yu et al., 2005; Nowak et al., 2006), and Pittsburgh (Yu et al., 2005). The majority of these studies found that the assumption of the existence of thermodynamic equilibrium between the gas and the condensed phases of inorganic composition of $\mathrm{PM}_{2.5}$ was valid to within the errors of the measurements.

AURAMS is a size- and composition-resolved, regional particulate matter and gas modelling system developed by Environment Canada for forecasts of regional air pollution and policy scenario simulations. The model consists of three principal components: (i) a prognostic meteorological model: Global Environmental Multiscale model, GEM (Cote et al., 1998), (ii) an emissions processing system: Sparse Matrix Operator Kernel Emissions, SMOKE (Houyoux et al., 2000; CEP, 2003), and (iii) an offline regional chemical transport model: the AURAMS Chemical Transport Model, CTM (Zhang et al., 2002; Makar et al., 2003; Gong et al., 2006). The CTM makes use of HETV (Makar et al., 2003) for thermodynamic partitioning of chemical species; a vectorized equilibrium solver based on the algorithms of ISORROPIA. In order to make accurate predictions of inorganic aerosol composition, an air quality model must provide accurate representations of meteorology, precursor emissions, oxidant fields, and gas/particle partitioning. In the case of $p \mathrm{NO}_{3}^{-}$predictions, the model is especially sensitive to inputs because of the strong temperature and humidity dependences (Eqs. 1 and 2), and the critical dependence on the availability of ammonia. In a recent assessment of the CMAQ model (Binkowski and Roselle, 2003; Mebust et al., 2003), which also uses the ISORROPIA inorganic equilibrium module, $\mathrm{Yu}$ et al. (2005) found that the performance of the model for particulate nitrate was strongly dependent on the ability of the model to accurately predict TA, TN, and $\mathrm{pSO}_{4}^{2-}$. Furthermore, the bias in TA in the model was found to be more critical to the accurate prediction of $p \mathrm{NO}_{3}^{-}$than the bias in $\mathrm{pSO}_{4}^{2-}$. From the sensitivity studies with ISORROPIA, Yu et al. (2005) concluded that the model predictions of $p \mathrm{NO}_{3}^{-}$ were also sensitive to the errors in $T$ and $\mathrm{RH}$ and that an error of $\pm 20 \%$ in both $T$ and RH can result in significant bias in predicted $\mathrm{pNO}_{3}^{-}$mass loadings $(<42 \%$ of the points were reproduced to within a factor of 1.5 of the input due to the bias in $T$ and $\mathrm{RH}$ ).

The Border Air Quality and Meteorology Study (BAQSMet) was an intensive, collaborative field campaign during the summer of 2007 that investigated the effects of transboundary pollution, local pollution, and local meteorology on regional air quality in southwestern Ontario. Air pollution formation in this region is quite complex because local lake- and thermally-forced meteorological circulation interacts with local emissions, and long-range transport of pollutants, to generate some of the highest levels of ozone and $\mathrm{PM}_{1}$ in Canada. The composition of $\mathrm{PM}_{1}$ during the campaign was monitored by a network of ground-based and airborne Aerosol Mass Spectrometers (AMS, Aerodyne Research Inc.) (Drewnick et al., 2005; DeCarlo et al., 2006). Instrument details along with supporting meteorological and gas phase measurements relevant to our analysis are described in Sect. 2.

The goal of this paper is to evaluate the ability of AURAMS to predict the speciation and mass loadings of the inorganic fraction of atmospheric $\mathrm{PM}_{1}$ during BAQS-Met. A special emphasis was placed on the agreement between $p \mathrm{NO}_{3}^{-}$predictions and measurements (Sect. 3.1). In order to investigate the thermodynamic partitioning as a potential source of large bias in nitrate predictions we performed a series of sensitivity tests by using the ISORROPIA thermodynamic partitioning model in an offline mode (Sect. 3.2). Following this comparison, we develop a framework to assess the sensitivity of $\mathrm{pNO}_{3}^{-}$mass loadings to variability in meteorological and chemical variables used by the model (Sect. 3.3). In Sect. 3.4, we examine the model bias in the availability of ammonia, and in Sect. 3.5, we carry out some model sensitivity tests by replacing the modelled meteorology with measured temperature and relative humidity. 


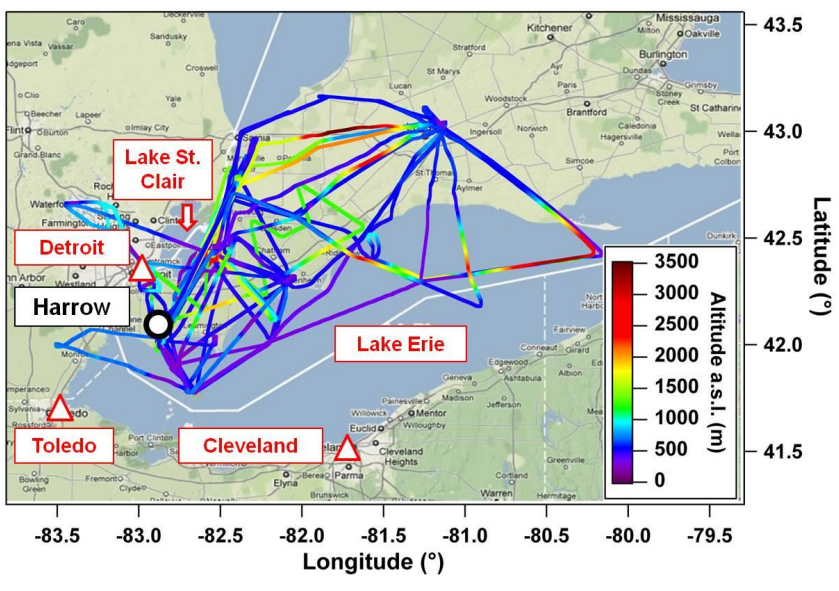

Fig. 1. Map of the BAQS-Met region showing the location of Harrow and the flight tracks of the Twin Otter research aircraft coloured by altitude.

\section{Experimental}

\subsection{Research aircraft}

Sixteen research flights (33 project hours) with the NRC's Twin Otter research aircraft were completed between 23 June and 8 July 2007. Research flights were carried out throughout southwestern Ontario and included multiple passes over Lake Erie and Lake St. Clair to investigate the effects of lake breezes on processing of pollutants (Fig. 1). Vertical profile measurements of trace pollutants were made over land and over the lakes during several day and night flights. In this project, we include the analysis of aircraft data over all flights.

The inorganic composition of $\mathrm{PM}_{1}$ was measured with a compact time-of-flight aerosol mass spectrometer (c-ToFAMS, Aerodyne Research, Inc., Billerica, MA, USA) which has been described in detail in the literature (Drewnick et al., 2005; DeCarlo et al., 2006). Briefly, the AMS consists of an aerodynamic lens that focuses particles $<1 \mu \mathrm{m}$ into a narrow beam, a chopper and time-of-flight chamber for sizeselective separation of particles, a thermal vaporization plate with an ionizer for Electron Impaction (EI) of the vapourized particles, and a time-of-flight mass spectrometer for the analysis of ionized fragments. The AMS provided mass concentrations of sulphate, ammonium and nitrate with a time resolution of $30 \mathrm{~s}$. A pressure controlled inlet (PCI) was used in front of the AMS to remove variations in particle sizing and transmission due to pressure changes in the aerodynamic lens of the AMS (Bahreini et al., 2008; Hayden et al., 2008, 2011). Transmission efficiency experiments indicated that particles were transmitted through the PCI with near 100 $\%$ efficiency. The particle collection efficiency (CE) for the AMS, i.e. the fraction of particles that hit the vaporizer and are vaporized, has been described in detail in the literature
(Drewnick et al., 2005; Kleinman et al., 2008; Dunlea et al., 2009) and is typically evaluated through comparisons with other instruments. The CE in this study was determined to vary between 0.5 and 1 as a function of particle acidity and the mass loadings reported in this paper have been adjusted as described in Hayden et al. (2011). The detection limits (determined as 3 times the standard deviation of mass concentrations for $30 \mathrm{~s}$ filtered samples) were $0.073,0.024$, and $0.014 \mu \mathrm{g} \mathrm{m}^{-3}$ for $p \mathrm{NH}_{4}^{+}, p \mathrm{SO}_{4}^{2-}$, and $p \mathrm{NO}_{3}^{-}$respectively. Uncertainty in the measurements is estimated at $\pm 20 \%$. For comparison to model output, the observations were averaged to $2 \mathrm{~min}$.

The ambient temperature was measured with a Rosemount temperature probe mounted on the nose of the aircraft; measurement uncertainty is $\pm 1 \%$. The relative humidity was calculated using the measured dew point and temperature and the estimated error is $\pm 4 \%$.

\subsection{Harrow monitoring site}

The Harrow supersite was located in Harrow, ON $\left(42.033^{\circ} \mathrm{N}, 82.893^{\circ} \mathrm{W}\right)$, about $5 \mathrm{~km}$ north of Lake Erie and about $30 \mathrm{~km}$ southeast of the Detroit-Windsor metropolitan area (Fig. 1). Measurements were made from 17 June to 11 July 2007. The site was subject to frequent inflows of transboundary pollution from Michigan to the west and Ohio to the south. More locally, the atmospheric composition at the site was often influenced by afternoon lake breezes from Lake Erie to the south and less frequently from Lake St. Clair to the north. Harrow is located in a rural area dominated by agricultural activities, mainly the cultivation of corn, soybeans, and fruit.

A c-ToF-AMS similar to that onboard the research aircraft (see above) was deployed to measure the composition of atmospheric $\mathrm{PM}_{1}$ at the ground site. Instrument collection efficiency was estimated by the acquisition of single particle mass spectra in conjunction with particle counting by an optical scattering module (Cross et al., 2009), which provides a light scattering pulse for particles larger than $\sim 215 \mathrm{~nm}$. The collection efficiency was estimated as the fraction of optically-detected particles yielding single particle mass spectra above background levels, and this ratio was assumed to apply across the entire detectable size range of the AMS (Slowik et al., 2010). The vaporization of sulphate and bisulphate species in the AMS produces $\mathrm{H}_{2} \mathrm{SO}_{4(\mathrm{~g})}$, $\mathrm{SO}_{3(\mathrm{~g})}$, and $\mathrm{H}_{2} \mathrm{O}_{(\mathrm{g})}$, with the ratios of these species dependent on particle composition. $\mathrm{H}_{2} \mathrm{SO}_{4(\mathrm{~g})}$ and $\mathrm{SO}_{3(\mathrm{~g})}$ are treated separately in the AMS spectral analysis, with the $\mathrm{H}_{2} \mathrm{O}_{(\mathrm{g})}$ formed in equal molar quantities with $\mathrm{SO}_{3(\mathrm{~g})}$, and the total reported sulphate + bisulphate concentration is the sum of $\mathrm{H}_{2} \mathrm{SO}_{4(\mathrm{~g})}$, $\mathrm{SO}_{3(\mathrm{~g})}$ and calculated $\mathrm{H}_{2} \mathrm{O}_{(\mathrm{g})}$ (Allan et al., 2004). Detection limits at 5 min time resolution were determined to be $0.200,0.014$, and $0.006 \mu \mathrm{g} \mathrm{m}^{-3}$ for $p \mathrm{NH}_{4}^{+}, p \mathrm{SO}_{4}^{2-}$ and $p \mathrm{NO}_{3}^{-}$respectively. Uncertainty in 
measurements was estimated to be $\pm 20 \%$. Data were acquired at $5 \mathrm{~min}$ time resolution and averaged to $30 \mathrm{~min}$ time steps for our analysis of ground-based data.

Gas phase measurements of ammonia were made using a Quantum Cascade Tunable Infrared Laser Differential Absorption Spectrometer (QC-TILDAS), developed by Aerodyne Research Inc. (Billerica, Massachusetts). Data were acquired with a time resolution of $1 \mathrm{~Hz}$ using a specially designed heated quartz inlet (Ellis et al., 2010) to minimize interferences and sampling biases. Further description of the QC-TILDAS along with a detailed analysis of ammonia during BAQS-Met can be found in Ellis et al. (2011). $\mathrm{NH}_{3(\mathrm{~g})}$ data averaged to $30 \mathrm{~min}$ were used in our analysis.

A chemiluminescence-based $\mathrm{NO} / \mathrm{NO}_{\mathrm{x}}$ instrument (Thermo Scientific Model 42C) was modified to conduct measurements of $\mathrm{NO}, \mathrm{NO}_{2}$ and $\mathrm{NO}_{\mathrm{y}}$, where $\mathrm{NO}_{\mathrm{y}}$ is defined as the sum of all nitrogen oxides $\left(\mathrm{NO}_{\mathrm{y}}=\mathrm{NO}+\mathrm{NO}_{2}+\mathrm{HNO}_{3}+\mathrm{PAN}+\mathrm{HONO}+\mathrm{NO}_{3}\right.$ radical + $2 \cdot \mathrm{N}_{2} \mathrm{O}_{5}+$ gaseous organic nitrates + semi-volatile $\left.p \mathrm{NO}_{3}^{-}\right)$. A photolytic converter unit from Ecophysics (model PLC $760 \mathrm{MH}$ ) was used to selectively convert $\mathrm{NO}_{2}$ to $\mathrm{NO}$, and a molybdenum converter heated at $325^{\circ} \mathrm{C}$ was used to reduce all $\mathrm{NO}_{\mathrm{y}}$ species to NO. The photolytic converter was operated inside the building, while the molybdenum converter unit was housed outside to minimize the losses for the reactive $\mathrm{NO}_{\mathrm{y}}$ components such as $\mathrm{HNO}_{3}, \mathrm{HONO}$ and $\mathrm{NO}_{3}$ radical. For this analysis, we used $\mathrm{NO}_{\mathrm{z}}\left(\equiv \mathrm{NO}_{\mathrm{y}}-\mathrm{NO}_{\mathrm{x}}\right)$ as a constraint on $\mathrm{TN}$ levels at Harrow. $\mathrm{NO}_{\mathrm{z}}$ is calculated as the difference between measurement of NO following the molybdenum converter and NO following the photolytic converter, after correction for conversion efficiency. Data were available at $1 \mathrm{~min}$ time resolution and averaged to 30 min time steps for our analysis.

Relative humidity and temperature measurements were made via Orion Weather Station ${ }^{\mathrm{TM}}$ from Columbia Weather Systems Inc. (Hillsboro, Oregon) with 1 min resolution. The uncertainties were $\pm 1.5 \%$ for $T$ and $\pm 4 \%$ for RH. Measurements averaged to $30 \mathrm{~min}$ were used in our analysis.

\subsection{AURAMS Model}

AURAMS version 1.4.0 was used for the simulations during BAQS-Met. The model was run in forecast mode with $15 \mathrm{~km}$ resolution during the campaign to guide the research aircraft and mobile ground-based platforms. After the campaign, a new high-resolution nested version of AURAMS was re-run for BAQS-Met with three levels of nesting: a $2.5 \mathrm{~km}$ grid-size high-resolution local domain nested within a $15 \mathrm{~km}$ regional domain, nested in turn within a $42 \mathrm{~km}$ North American domain. The model ran with a 2 min time step for the innermost local domain and a 15 min time step on the two larger domains. The two lower resolution simulations make use of $15 \mathrm{~km}$ grid spacing meteorological input from the GEM (v3.2.2 with physics version 4.5), while the higher resolution AURAMS simulation made use of GEM output in a $2.5 \mathrm{~km}$ grid spacing configuration (Makar et al., 2010b). All three levels of nesting employed a monthly-varying upper boundary condition for all advected chemical species. The outermost domain also made use of time-invariant and vertically-varying chemical lateral boundary conditions, with the exception of ozone, for which a dynamic tropopausereferenced boundary condition was applied (Gong et al., 2006; Makar et al., 2010a). In this analysis, the output from the highest resolution AURAMS simulation $(2.5 \mathrm{~km}$ with 2 min time steps) was used.

SMOKE version 2.2 was utilized to drive the emission component of AURAMS by processing anthropogenic emission inventories from 2005 for the US (EPA) and 2006 for Canada (EC). The inventories included 17 gas phase species and primary $\mathrm{PM}_{2.5}$ and $\mathrm{PM}_{10}$ emissions. Major point source emissions in the model domain (e.g. power plants) were corrected by using CEM (Continuous Emission Monitor) data. Biogenic emissions were calculated "online" via BEIS3.09 algorithms with model-generated temperatures and photosynthetically active radiation. Version 1.4.0 of AURAMS CTM included the following processes: (i) gas phase, aqueous phase, and inorganic heterogeneous chemistry, (ii) particle nucleation, condensation, coagulation, sedimentation, activation, and secondary organic particle formation, (iii) dry and wet deposition, (iv) emissions from the surface and elevated sources, and (v) horizontal and vertical advection, and vertical diffusion. The model's gas phase chemical mechanism is a modified version of ADOM-II mechanism (Lurmann et al., 1986), which includes 42 gas phase species and 114 reactions and is solved using a version of the predictorcorrector method of Young and Boris (1977). AURAMS employs a sectional representation of the PM size spectrum. PM is represented by 12 size (diameter) bins in the AURAMS output, each including 9 chemical species. $\mathrm{PM}_{1}$ mass loadings were calculated as the sum of bins 1 through 6 plus 0.042 bin 7. As described above, AURAMS makes use of HETV (Makar et al., 2003), a vectorized equilibrium solver based on the algorithms of ISORROPIA, for thermodynamic partitioning of chemical species. In this configuration, the model was run with the "metastable state" option on, which treats all particles as exclusively aqueous and prevents crystalline solid formation in the model output. More information about the model can be found in (Makar et al., 2003, 2010b; Gong et al., 2006).

\subsection{ISORROPIA}

ISORROPIA v2.1 (Fountoukis and Nenes, 2007) was used for all offline re-partitioning work including a series of sensitivity tests. All of the runs in ISORROPIA were performed in "forward mode" where TA, TS, TN, relative humidity and temperature were entered and the model was allowed to repartition the species between the gas and particle phase according to its thermodynamic algorithms. All runs were executed with the "metastable state" option on (efflorescent 
Table 1. Statistical evaluation of modelled and measured inorganic $\mathrm{PM}_{1}$ mass loadings at the ground and aloft during BAQS-Met. $\mathrm{M}_{\text {mod }}=$ modelled mean, $\mathrm{M}_{\mathrm{obs}}=$ observed mean, $\mathrm{MB}=$ mean bias, $\mathrm{ME}=$ mean error, $\mathrm{NMB}=$ normalized mean bias, $\mathrm{NME}=$ normalized mean error, RMSE $=$ root mean square error, and $R=$ correlation coefficient.

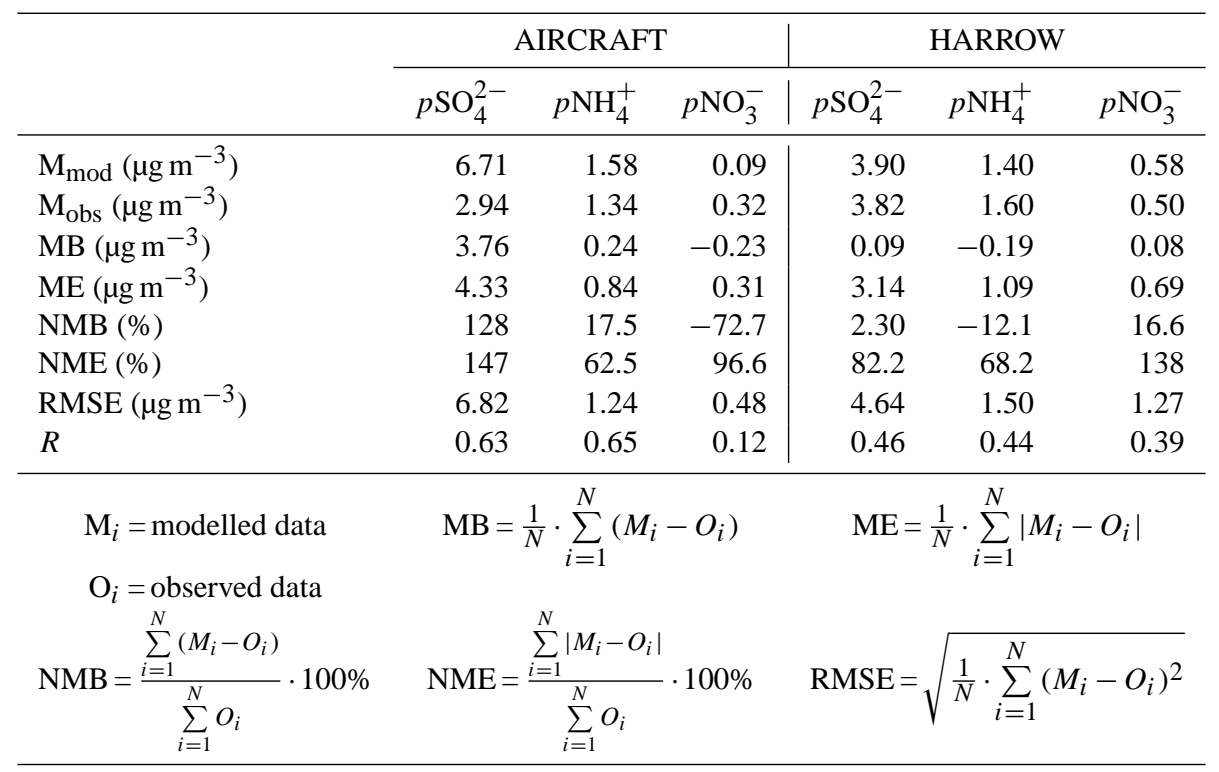

branch). Both observations and AURAMS output were separately entered into ISORROPIA and re-partitioned in these studies. We restricted the re-partitioning analysis for the measurements and the model to time points for which there were valid measurements of TA, TS, TN, RH and $T$. ISORROPIA output, including mass loadings of $\mathrm{NH}_{3(\mathrm{~g})}, \mathrm{NH}_{4}^{+}$(aq), $\mathrm{HSO}_{4}^{-}(\mathrm{aq}), \mathrm{SO}_{4}^{2-}{ }_{(\mathrm{aq})}, \mathrm{HNO}_{3(\mathrm{~g})}$, and $\mathrm{NO}_{3}^{-}$(aq) was compared to the original modelled and measured data. We focused our sensitivity studies on the ground-based data because the additional measurements of $\mathrm{NH}_{3(\mathrm{~g})}$ and $\mathrm{NO}_{\mathrm{Z}}$ (not available on the aircraft) provided better constraints on the levels of TA and TN.

\section{Results and discussion}

\subsection{The comparison between measured and modelled inorganic composition of $\mathbf{P M}_{1}$}

\subsubsection{Harrow data}

AURAMS-modelled $\mathrm{PM}_{1}$ sulphate and AMS sulphate measurements in Harrow (Fig. 2a) were reasonably well correlated (Table 1) throughout the campaign with three major exceptions that occurred during 19-20 June, 24-29 June and 10-11 July periods. These periods were characterized by air masses originating from the high emission region of the Ohio Valley, which is a well-established contributor to $\mathrm{SO}_{2}$, $\mathrm{NO}_{\mathrm{x}}$ and $\mathrm{PM}_{1}$ pollution in southwestern Ontario (Canada United States Transboundary Particulate Matter Science As- sessment, 2004). During these periods of high $\mathrm{PM}_{1}$, AURAMS was biased high for sulphate compared to measured data. In some instances the model predicted 2-3 times higher mass loadings. However, some of this bias may actually be attributable to the falloff in transmission efficiency of the AMS between $0.4-1 \mu \mathrm{m}$. Particle size distributions measured by the AMS at Harrow suggest that, particularly at high mass loadings, significant sulphate mass may be present above the nominal size cut. Overall at Harrow, AURAMS had a low mean bias (Table 1) for $p \mathrm{SO}_{4}^{2-}\left(\mathrm{MB}=0.09 \mu \mathrm{g} \mathrm{m}^{-3}\right)$, but a substantial RMSE $\left(4.64 \mu \mathrm{g} \mathrm{m}^{-3}\right)$. Modelled $p \mathrm{NH}_{4}^{+}$ (Fig. 2b) was biased low ( $\mathrm{MB}=-0.19 \mu \mathrm{g} \mathrm{m}^{-3}$ ), also with a large RMSE $=1.50 \mu \mathrm{g} \mathrm{m}^{-3}$.

AURAMS tended to predict more extreme values of $\mathrm{PM}_{1}$ nitrate than those measured by the AMS (Fig. 2c). While AURAMS frequently predicted zero, AMS observations were rarely below the detection limit. On the other hand, AURAMS tended to predict much higher mass loadings when the observations indicated significant levels of nitrate. As a result, while the mean bias appears small $\left(\mathrm{MB}=0.08 \mu \mathrm{g} \mathrm{m}^{-3}\right)$, the RMSE is very large $\left(1.27 \mu \mathrm{g} \mathrm{m}^{-3}\right)$. Because the model predicted peaks in $p \mathrm{NO}_{3}^{-}$at approximately the same times of day as the observations, the correlation coefficient $(R=0.39)$ is higher than it might otherwise be. 


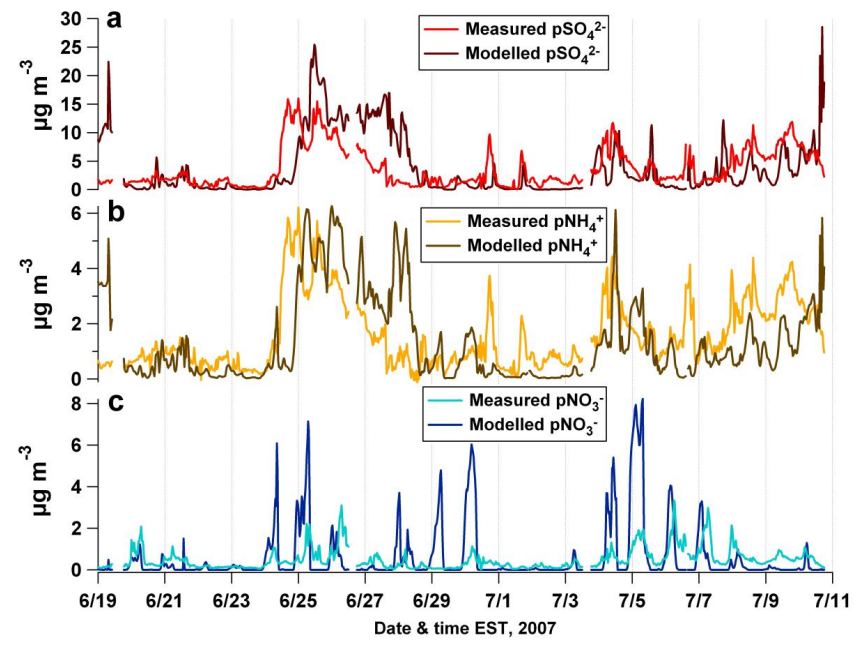

Fig. 2. Time series of measured and modelled $30 \mathrm{~min}$ averages of (a) $\mathrm{SO}_{4}^{2-}$, (b) $p \mathrm{NH}_{4}^{+}$and (c) $\mathrm{pNO}_{3}^{-}$at the Harrow, ON site during BAQS-Met.
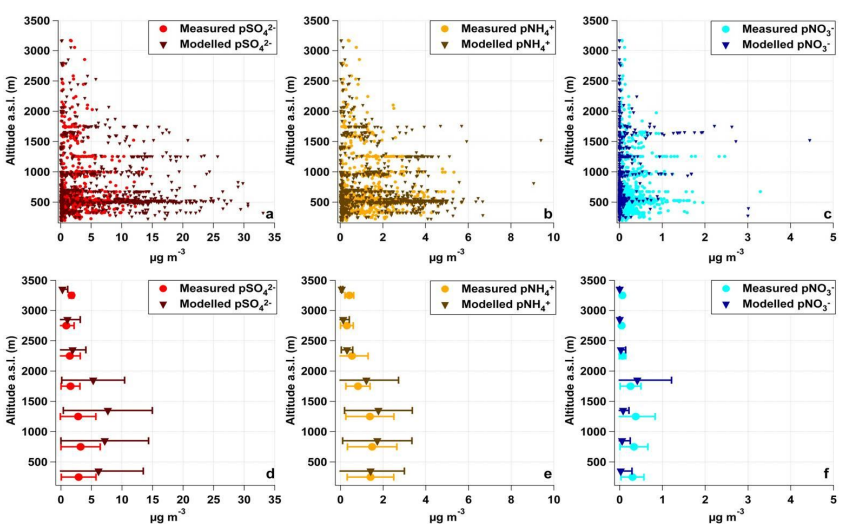

Fig. 3. Vertical distributions of measured and modelled 2 min averages of of (a) $\mathrm{pSO}_{4}^{2-}$, (b) $p \mathrm{NH}_{4}^{+}$and (c) $p \mathrm{NO}_{3}^{-}$and averages of $500 \mathrm{~m}$ altitude bins (showing \pm 1 standard deviation) for (d) $\mathrm{pSO}_{4}^{2-}$, (e) $p \mathrm{NH}_{4}^{+}$and (f) $p \mathrm{NO}_{3}^{-}$from the Twin Otter aircraft over all flights during BAQS-Met.

\subsubsection{Aircraft data}

Compared to the evaluation of the model predictions at the ground site, the evaluation of aircraft data poses the additional challenges of (i) the simultaneous evaluation of predictions in both time and space, and ii) the precise nature of the relatively fast aircraft measurements vs. $2.5 \mathrm{~km}$ grid resolution constraining the evaluation. Both modelled sulphate (Fig. 3a, d) and ammonium (Fig. 3b, e) were biased high relative to observations for most of the flights and the bias was more significant for time periods characterized by high $\mathrm{PM}_{1}$ levels. The positive bias in $\mathrm{pSO}_{4}^{2-}$ was much larger than that for $p \mathrm{NH}_{4}^{+}$, even in terms of equivalents, resulting in predictions of aerosol that were more acidic than indicated by the observations. This contributed to a normalized mean bias in $p \mathrm{NO}_{3}^{-}$of $-72.7 \%$. The model seldom predicted significant nitrate mass loadings $\left(>1 \mu \mathrm{g} \mathrm{m}^{-3}\right)$ aloft, but when it did, the predictions were also biased high relative to the AMS observations (Fig. 3c, f). Thus, a very low correlation coefficient ( $R=0.12$ ) is found between modelled and measured aircraft $p \mathrm{NO}_{3}^{-}$data (Table 1).

\subsubsection{The influence of plume effects on the model/measurement agreement}

While the data in Table 1 and Figs. 2 and 3 demonstrate that AURAMS did accurately predict the overall magnitude of regional nitrate mass loadings during the BAQS-Met campaign, individual observations both at a specific ground site and in the lowest $3000 \mathrm{~m}$ aloft were not well-represented by the model. Because point sources (e.g. power plants) or vehicle sources are expected to be the dominant sources of $\mathrm{SO}_{2}$ and $\mathrm{NO}_{\mathrm{x}}$ in the region, one explanation of the large RMSE for $\mathrm{NOO}_{3}^{-}$is inaccurate predictions of when plumes are influencing the measurements. The erroneous placement of a plume from a power plant, road, or urban area in space or time due to inaccurate representations of advection or diffusion could lead to poor correlations on short timescales. In addition, the spatial resolution of AURAMS is currently limited to a $2.5 \mathrm{~km} \times 2.5 \mathrm{~km}$ grid box which is larger than the spatial extent of most plumes. To examine the significance of these "hit-and-miss" instances on the agreement between measurements and predictions of $\mathrm{PM}_{1}$ composition, we examine the data through a series of histograms. The histogram shown in Fig. 4 illustrates the range of measurements and predictions of $p \mathrm{NO}_{3}^{-}$. All modelled values lower than $0.01 \mu \mathrm{g} \mathrm{m}^{-3}$ were accumulated into the lowest bin in the figure. The great majority of aircraft measurements were made within the boundary layer during daytime (Hayden et al., 2011). Most of the nitrate mass loadings measured by the aircraft AMS were between 0.1 and $1 \mu \mathrm{g} \mathrm{m}^{-3}$. In comparison to aircraft measurements, the mass loadings of $\mathrm{pNO}_{3}^{-}$at the Harrow site were slightly higher, as evident by greater frequency of points in 1 to $4 \mu \mathrm{g} \mathrm{m}^{-3}$ range.

While the measured average mass loading of $p \mathrm{NO}_{3}^{-}$at Harrow was higher than that aloft (Table 1), both datasets are well-represented by a log-normal distribution. In contrast, the model predicts a much wider range of particulate nitrate, with a significant fraction of the data predicted to be below the detection limit of the AMS. However, only $0.1 \%$ of the observations at Harrow and $1.3 \%$ of the aircraft observations were in fact below the detection limit. If hit-and-miss errors were the significant driver of model bias, we would expect the overall distribution to be well-represented by the model, even if the point-to-point comparisons were not good. Because the distributions of nitrate mass loadings predicted by the model do not match the distributions observed from the aircraft or on the ground, we can conclude that inaccurate plume placement is not the main reason for disagreement 


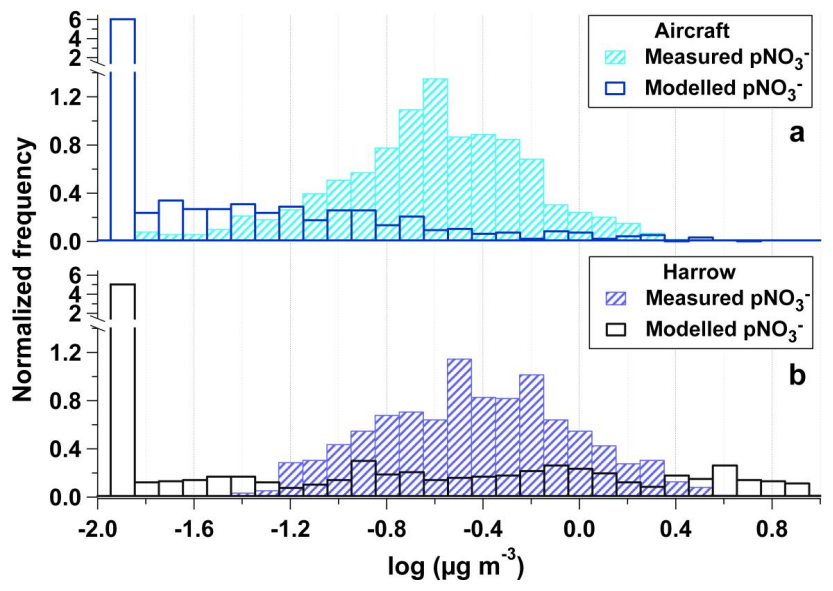

Fig. 4. Normalized histograms of the measured and modelled $p \mathrm{NO}_{3}^{-}$mass loadings (a) from the Twin Otter aircraft (b) at Harrow.

between the model and the measurements. We now examine alternative explanations for the disagreement in the remainder of the paper.

\subsection{The applicability of thermodynamic equilibrium at Harrow}

In order to determine whether the ammonium-sulphatenitrate system was in thermodynamic equilibrium, Harrow measurements were re-partitioned using ISORROPIA. At Harrow, TA values were calculated using the sum of $\mathrm{NH}_{3(\mathrm{~g})}$ measurements by QC-TILDAS and $p \mathrm{NH}_{4}^{+}$measurements by AMS. TS values were represented by AMS $p \mathrm{SO}_{4}^{2-}$. AMS $p \mathrm{SO}_{4}^{2-}$ is a good proxy for TS for three reasons: (i) the vapour pressure of $\mathrm{H}_{2} \mathrm{SO}_{4}(\mathrm{~g})$ is low and it is expected to be exclusively in condensed phase in the atmosphere, (ii) AMS $p \mathrm{SO}_{4}^{2-}$ is actually the sum of particulate bisulphate $\left(\mathrm{HSO}_{4}^{-}\right.$), sulphate $\left(\mathrm{SO}_{4}^{2-}\right)$ and sulphuric acid $\left(\mathrm{H}_{2} \mathrm{SO}_{4}\right)$, and (iii) most of the $\mathrm{SO}_{4}^{2-}$ is expected to be at particle sizes less than $1 \mu \mathrm{m}$ diameter. The lack of specific $\mathrm{HNO}_{3(\mathrm{~g})}$ measurements at the site precluded an exact calculation of TN from direct observations. We estimated $\mathrm{TN}$ as a fraction of the $\mathrm{NO}_{\mathrm{z}}$ measurements from the chemiluminescence analyzer. We re-partitioned the data assuming (i) a low TN case, $\mathrm{TN}=\mathrm{AMS} p \mathrm{NO}_{3}^{-}$, (ii) a medium TN case, $\mathrm{TN}=0.5 \cdot \mathrm{NO}_{\mathrm{z}}$, and (iii) a high $\mathrm{TN}$ case, $\mathrm{TN}=\mathrm{NO}_{\mathrm{z}}$. The medium $\mathrm{TN}$ case provided the most reasonable $\mathrm{TN}$ concentrations because the re-partitioned $p \mathrm{NO}_{3}^{-}$agreed most closely with the $\mathrm{NO}_{3}^{-}$observed by the AMS. Therefore, we calculated $\mathrm{HNO}_{3(\mathrm{~g})}$ by subtracting AMS $p \mathrm{NO}_{3}^{-}$from TN obtained by $\mathrm{TN}=0.5 \cdot \mathrm{NO}_{\mathrm{z}}$. While our approximation for $\mathrm{TN}$ is likely not consistently valid throughout the campaign, it provides a reasonable range of $p \mathrm{NO}_{3}^{-}$values and there is no justification for adopting a variable fraction. This analysis could
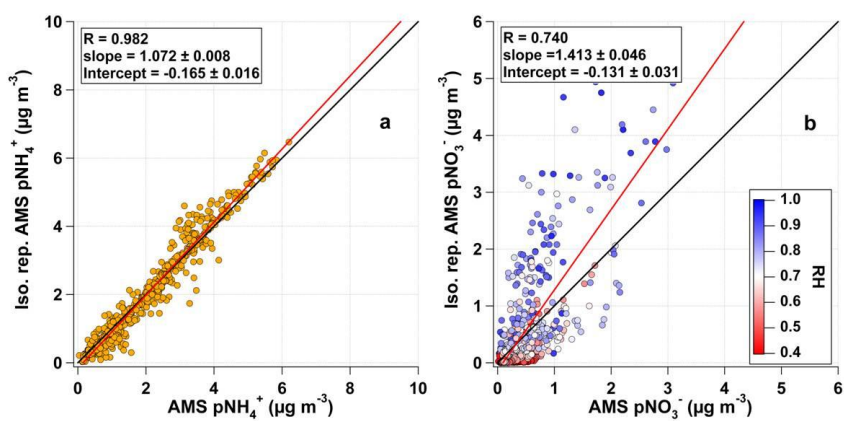

Fig. 5. Scatter plots between re-partitioned and measured (a) $\mathrm{pNH}_{4}^{+}$and (b) $\mathrm{pNO}_{3}^{-}$, coloured by relative humidity, at Harrow. The black line is $1: 1$, and the red line is the least squares fit.

not be carried out for the aircraft data because of the lack of $\mathrm{NH}_{3(\mathrm{~g})}$ and $\mathrm{NO}_{z}$ measurements.

Observed Harrow TA, TS, TN, RH and $T$ values were used as inputs to ISORROPIA and the model was allowed to re-partition the data between the gas and the particle phase assuming thermodynamic equilibrium conditions. The repartitioned data were in very good agreement with the original measurements suggesting that the ammonium-sulphatenitrate system was in thermodynamic equilibrium in Harrow. According to ISORROPIA, TS was almost exclusively in the form of $\mathrm{SO}_{4}^{2-}$ as opposed to $\mathrm{HSO}_{4}^{-}$. In terms of neutralization of the ammonium-sulphate-nitrate system this means that $\mathrm{PM}_{1}$ sulphate was completely neutralized and that thermodynamic formation of particulate ammonium nitrate is possible under such conditions. Re-partitioned TA was in good agreement with the original observations suggesting that most of the $p \mathrm{NH}_{4}^{+}$is contained in particles with diameter $<1 \mu \mathrm{m}$, and that the observed species are sufficient to describe the system. The scatter plot of re-partitioned $p \mathrm{NH}_{4}^{+}$ versus AMS $p \mathrm{NH}_{4}^{+}$has a slope of 1.072 and $R=0.982$ (Fig. 5a). The close agreement between observed and repartitioned $p \mathrm{NH}_{4}^{+}$also suggests that the estimated values for $\mathrm{TN}$ were not unreasonable.

The scatter plot (Fig. 5b) between the re-partitioned and original $p \mathrm{NO}_{3}^{-}$has a slope of $m=1.413$ and $R=0.74$, suggesting that ISORROPIA predicted, on average, more $p \mathrm{NO}_{3}^{-}$than measured. While the scatter appears significant, according to an average percent difference calculation, ISORROPIA predicted, on average, about $1 \%$ more $p \mathrm{NO}_{3}^{-}$ than observed. Most likely, $\mathrm{TN}=0.5 \cdot \mathrm{NO}_{\mathrm{z}}$ is, at least in some cases, an overestimate that leads to the overestimate in $p \mathrm{NO}_{3}^{-}$by the model in conditions of high TA. This is also consistent with a slope of greater than one for the $p \mathrm{NH}_{4}^{+}$ comparison (Fig. 5a). Predictions of high nitrate can also be attributed to increased $p \mathrm{NO}_{3}^{-}$formation due to dissolution of $\mathrm{HNO}_{3(\mathrm{~g})}$ in water (Fig. 5b). Under high RH conditions, the amount of $p \mathrm{NO}_{3}^{-}$that will form from dissolution in water is directly proportional to TN. For this reason, the repartitioned $p \mathrm{NO}_{3}^{-}$points that are furthest away from the 1:1 
line in the positive direction correspond to high RH regimes, as shown by colour scale. The fact that the re-partitioned TA data agrees well with the measured data and that repartitioned $\mathrm{TN}$ data agrees reasonably well (considering the constraints in TN measurements) suggests that gas/particle partitioning can be described by thermodynamic equilibrium expressions at Harrow during BAQS-Met. Thermodynamic equilibrium for fine PM was also observed in the field by Zhang et al. (2003), Nowak et al. (2006), and Fountoukis et al. (2009). In addition, Meng and Seinfeld (1996), Dassios and Pandis (1999), and Cruz et al. (2000) showed that the submicron particles $\left(\mathrm{PM}_{1}\right)$ have short equilibration time and will reach thermodynamic equilibrium on the order of minutes. Because the measurement site is not directly located next to a source that would strongly perturb the levels of $\mathrm{NH}_{3(\mathrm{~g})}$ or acidic aerosols, and an adequate representation of $p \mathrm{NO}_{3}^{-}$is achieved by the re-partitioning using ISORROPIA, it is expected that the HETV algorithms in AURAMS should appropriately describe the gas/particle partitioning.

\subsection{Free ammonia (FA) chemical maps}

In Sect. 3.2, we demonstrated that thermodynamic equilibrium expressions are appropriate to model the gas/particle partitioning of TA and TN. The accurate prediction of $p \mathrm{NO}_{3}^{-}$ will depend not only on accurate predictions of $\mathrm{TN}$, but also on $\mathrm{RH}, T$, and the availability of $\mathrm{NH}_{3(\mathrm{~g})}$, as a result of the equilibrium expressions in Eqs. (1) and (2). In order to assess the variables that control the ability of AURAMS to accurately predict $\mathrm{PM}_{1}$ nitrate, we examine the parameters governing the mass loading of particulate nitrate by using free ammonia chemical maps. Free ammonia is defined as FA $=$ TA -2 . TS (Seinfeld, 1996), where the factor of 2 accounts for the equivalents of sulphate. If FA of the ammonium-sulphate-nitrate system is positive, the system contains sufficient ammonia to form ammonium nitrate (particulate nitrate), depending on the $\mathrm{RH}$ and $T$ conditions. If FA is negative, the system does not contain sufficient ammonia and the formation of ammonium nitrate is thermodynamically unfavourable. At sufficiently high $\mathrm{RH}, \mathrm{HNO}_{3(\mathrm{~g})}$ may dissolve to form aqueous nitrate, even in the absence of high FA. In order to investigate the combined effects of absolute concentrations and meteorological variables on the formation of $\mathrm{pNO}_{3}^{-}$, as driven by algorithms of the model, we generated a series of FA chemical maps, an example of which is shown in Fig. 6.

The map in Fig. 6 was created by running ISORROPIA to predict $p \mathrm{NO}_{3}^{-}$mass loadings over a range of temperatures and FA values at a constant relative humidity $(0.65)$ and TN value $\left(100 \mathrm{nmol} \mathrm{m}^{-3} \equiv 6.2 \mu \mathrm{g} \mathrm{m}^{-3}\right)$. A range of FA values ( -275 to $275 \mathrm{nmol} \mathrm{m}^{-3}$ ) were generated by varying TS values while keeping TA constant at an atmospherically relevant level $\left(275 \mathrm{nmol} \mathrm{m}^{-3} \equiv 4.95 \mu \mathrm{g} \mathrm{m}^{-3}\right)$. The map space in Fig. 6 is coloured by the amount of nitrate predicted to be in particle phase for each combination of FA and $T$. By gener-

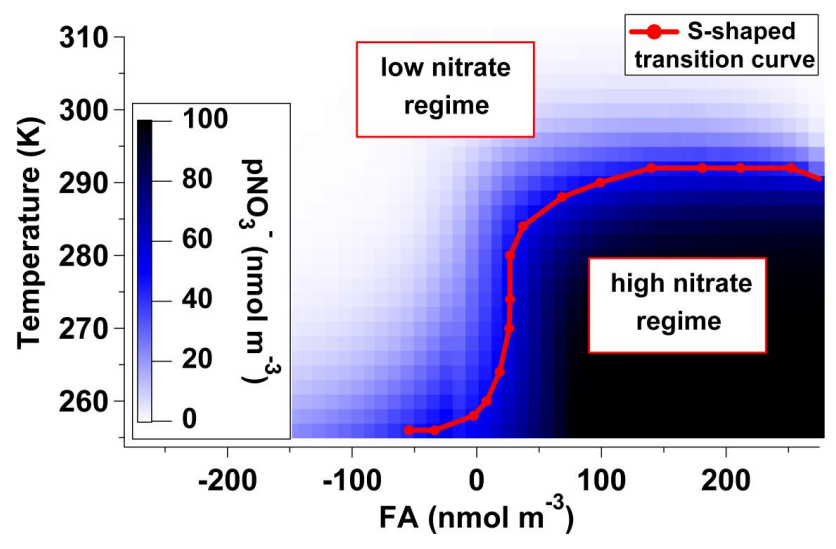

Fig. 6. FA chemical map illustrating the partitioning of TN to $p \mathrm{NO}_{3}^{-}$at $\mathrm{RH}=0.65$ for $T=255-310 \mathrm{~K}$. TA was held constant at $275 \mathrm{nmol} \mathrm{m}^{-3}$ and TS was varied between 0 and $275 \mathrm{nmol} \mathrm{m}^{-3}$ in order to generate a range of FA values that were observed during the field campaign (-275 to $275 \mathrm{nmol} \mathrm{m}^{-3}$ ). TN was held constant at $100 \mathrm{nmol} \mathrm{m}^{-3}$ and the map is coloured by the amount of nitrate in the particle phase in $\mathrm{nmol} \mathrm{m}{ }^{-3}$. The S-shaped transition curve, which is characterized by $p \mathrm{NO}_{3}^{-}=\mathrm{HNO}_{3(\mathrm{~g})}=0.5 \cdot \mathrm{TN}=50 \mathrm{nmol} \mathrm{m}^{-3}$, separates the FA chemical map into low and high $\mathrm{pNO}_{3}^{-}$regimes.

ating these maps, we can identify regimes in which the formation of particulate nitrate is favourable for a given pair of $T$ and FA values. It suggests that in order to form $>2 \mu \mathrm{g} \mathrm{m}^{-3}$ of particulate nitrate (given $6.2 \mu \mathrm{g} \mathrm{m}^{-3}$ of $\mathrm{TN}$ ) at $\mathrm{RH}=0.65$, temperatures must be lower than $295 \mathrm{~K}$, and if they are above $270 \mathrm{~K}$, FA must also be positive. The S-shaped transition region between where formation of nitrate is less favourable (light) and where the formation is more favourable (dark) is where the predictions of nitrate are most sensitive to model input parameters. It should be noted that the position of the transition region depends on $\mathrm{RH}$, as the formation of particulate nitrate becomes more pronounced at high water concentrations in the atmosphere. At high RH, the amount of water in the atmosphere is sufficiently high for the dissolution of $\mathrm{HNO}_{3(\mathrm{~g})}$ to form $\mathrm{pNO}_{3}^{-}$(aq) and become more important than chemically driven formation of nitrate through the reaction with $\mathrm{NH}_{3(\mathrm{~g})}$.

Figure 6 shows that temperature strongly impacts both predictions of particulate nitrate and their sensitivity to FA. Because the absolute amount of TN, the temperature and the relative humidity impact the predictions of particulate nitrate, we have generated a series of panels (Fig. 7) representing different scenarios relevant to the measurements during BAQS-Met. These partitioning maps were generated at three $\mathrm{RH}$ regimes (low $\mathrm{RH}=0.40$, medium $\mathrm{RH}=0.65$ and high $\mathrm{RH}=0.90)$ and three $\mathrm{TN}$ regimes (low $\mathrm{TN}=20 \mathrm{nmol} \mathrm{m}^{-3}$, medium $\mathrm{TN}=50 \mathrm{nmol} \mathrm{m}^{-3}$ and high $\mathrm{TN}=100 \mathrm{nmol} \mathrm{m}^{-3}$ ). TA was held constant at $275 \mathrm{nmol} \mathrm{m}^{-3}$ and TS was varied between 0 and $275 \mathrm{nmol} \mathrm{m}^{-3}$ in order to generate a range 

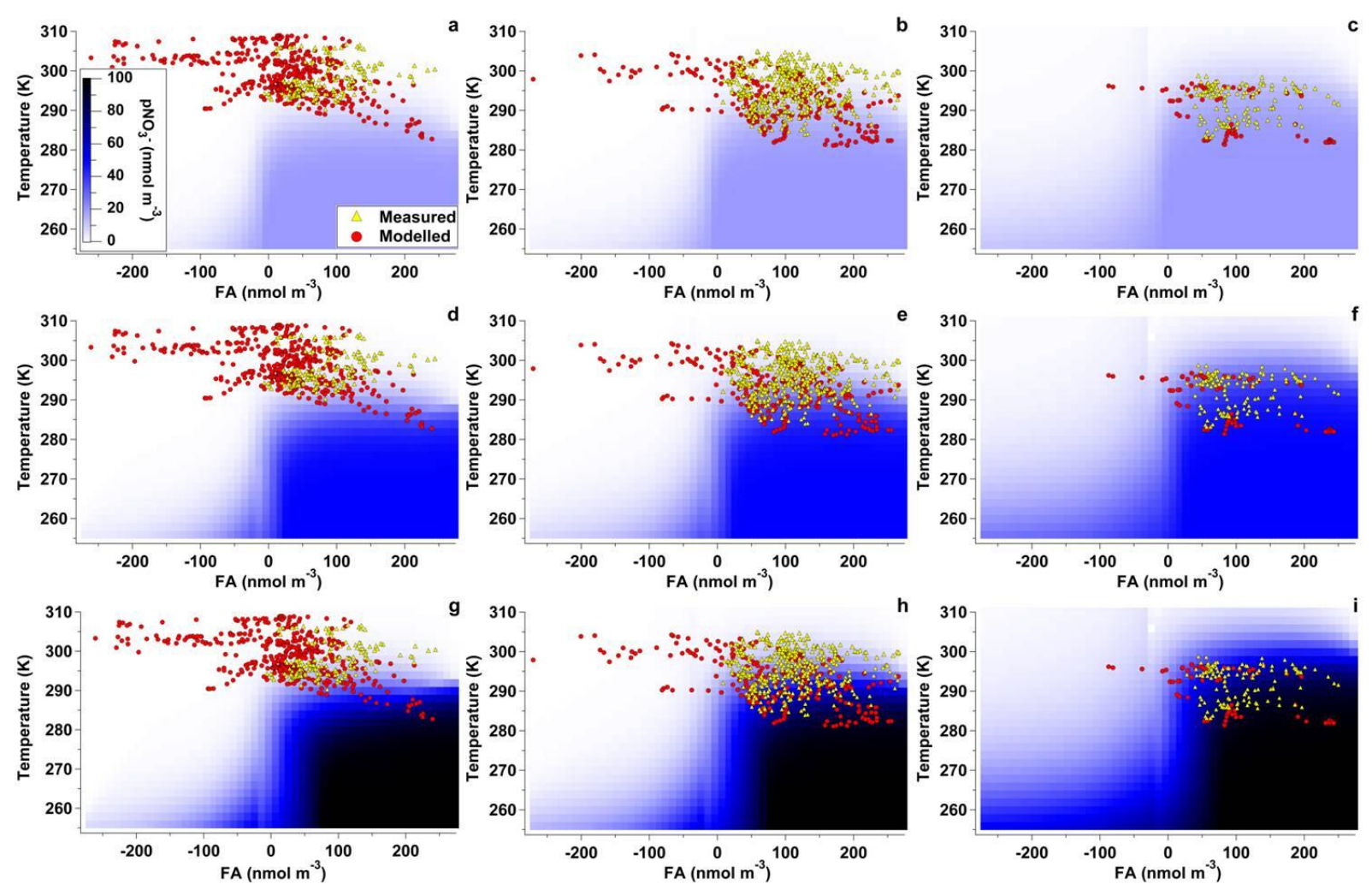

Fig. 7. FA chemical maps depicting the relationship between FA, meteorological data and the partitioning of TN. These maps were generated at three $\mathrm{RH}$ regimes (low $\mathrm{RH}=0.40(\mathbf{a}, \mathbf{d}, \mathbf{g})$, medium $\mathrm{RH}=0.65(\mathbf{b}, \mathbf{e}, \mathbf{h})$ and high $\mathrm{RH}=0.90(\mathbf{c}, \mathbf{f}, \mathbf{i}))$ and three $\mathrm{TN}$ regimes $($ low $\mathrm{TN}=20 \mathrm{nmol} \mathrm{m}^{-3}(\mathbf{a}, \mathbf{b}, \mathbf{c})$, medium $\mathrm{TN}=50 \mathrm{nmol} \mathrm{m}^{-3}(\mathbf{d}, \mathbf{e}, \mathbf{f})$ and high $\mathrm{TN}=100 \mathrm{nmol} \mathrm{m}^{-3}(\mathbf{g}, \mathbf{h}, \mathbf{i})$ ). RH increases from left to right (a) to (c) and TN increases from top the bottom (a) to (g). The maps are overlaid with measurements and model predictions from Harrow, averaged to $30 \mathrm{~min}$ time resolution, and sorted according to measured and modelled RH.

of FA values that were observed during the field campaign ( -275 to $275 \mathrm{nmol} \mathrm{m}^{-3}$ ). RH increases from left to right (a to c) and TN increases from top the bottom (a to g).

The AURAMS model predictions (red circles) and observations from Harrow (yellow triangles) are overlaid on the panels. AMS and AURAMS data were binned according to measured and modelled RH respectively in order to match three $\mathrm{RH}$ regimes (low $\mathrm{RH} \equiv 0-0.50$, medium $\mathrm{RH} \equiv 0.50$ 0.80 , and high $\mathrm{RH} \equiv 0.80-1.0)$ to account for the effect of $\mathrm{RH}$ on the formation of nitrate. For example, all measured and modelled data corresponding to the low RH bin are plotted on maps generated at $\mathrm{RH}=0.40$, because there is little variation in the characteristics of the maps at all $\mathrm{RH}<0.50$ in the temperature range observed during BAQS-Met. Data were not binned according to $\mathrm{TN}$ because the $\mathrm{NO}_{\mathrm{z}}$ measurements did not offer a strong constraint on $\mathrm{TN}$, so the same data appear on e.g. panels a, d, and g. At $\mathrm{RH}=0.65$, the average observed $\mathrm{RH}$ at Harrow, there is little variation in the position of the S-shaped transition region between the three TN regimes (Fig. 7b, e, and h). At high RH there is sufficient water in the atmosphere such that the dissolution of $\mathrm{HNO}_{3}(\mathrm{~g})$ in water completely outcompetes chemical formation of am- monium nitrate. This is evident from the vertical shift of the S-shaped transition region from Fig. 7d, e, and f.

As indicated by the colour scale, the absolute amount of particulate nitrate will significantly increase going from low to high TN concentrations. For an intermediate to high level of FA $\left(50-100 \mathrm{nmol} \mathrm{m}^{-3}\right)$, the higher the level of TN in the atmosphere, the more of it will partition into particle phase, both in relative and absolute terms. At high TN levels, FA becomes the limiting factor in the formation of particulate nitrate according to Eqs. (1 and 2). On these maps, both modelled and observed FA values are located close to the transition between the light region where the majority of $\mathrm{TN}$ is $\mathrm{HNO}_{3(\mathrm{~g})}$ and dark region where the majority of TN is $p \mathrm{NO}_{3}^{-}$. Most of the observations (yellow triangles) are located in the positive FA region of the map where significant $\mathrm{pNO}_{3}^{-}$formation is expected if temperatures are low. In contrast, the model points (red circles) are located across a wider range of FA and temperature values, producing a wider range of $p \mathrm{NO}_{3}^{-}$predictions. There is a pronounced bias in modelled FA in the low RH regime (Fig. 7 a, d, and g), but the chemical maps indicate that this causes little bias in $p \mathrm{NO}_{3}^{-}$because its formation is not favoured under these warm, dry conditions, 


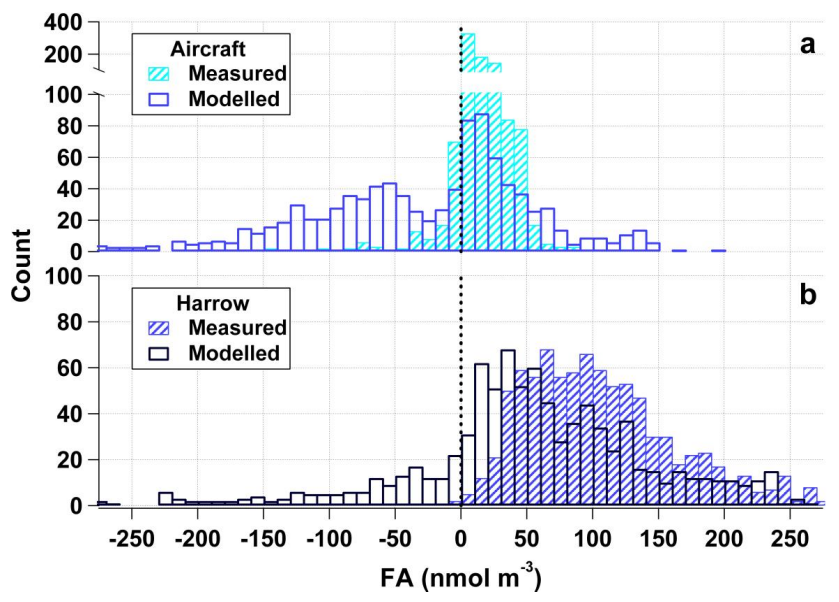

Fig. 8. Histogram of FA values calculated from measured and modelled TS and TA for (a) 2 min averages from the aircraft and (b) $30 \mathrm{~min}$ averages from the ground. The aircraft FA was calculated with $\mathrm{TA}=p \mathrm{NH}_{4}^{+}$due to lack of $\mathrm{NH}_{3(\mathrm{~g})}$ measurements aloft.
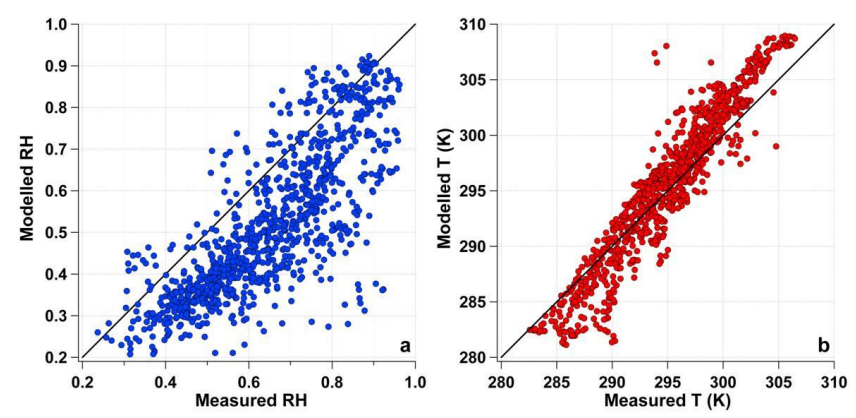

Fig. 9. Harrow modelled vs. measured (a) RH (b) $T$. The black line is the $1: 1$ line.

even at higher FA. The difference in the modelled and measured FA parameters on these partitioning maps can explain much of the discrepancy between modelled and measured nitrate mass loadings observed during BAQS-Met, especially at intermediate $\mathrm{RH}$ and assuming intermediate values of TN (Fig. 7e).

\subsection{Measured and modelled FA}

The bias in AURAMS FA values results either from overpredictions of TS, or underpredictions of TA. In Ellis et al. (2011), it is shown that the TA was consistently underpredicted at Harrow. To compare the range of measured and modelled FA values, we generated histograms of FA from the aircraft data (Fig. 8a) and at Harrow (Fig. 8b). Compared to FA values calculated from measurements, FA values predicted by AURAMS were distributed across a much wider range both at the ground and aloft. In addition, a significant number of modelled FA values were negative while all of the ground-based and $>95 \%$ of the aircraft measurements of
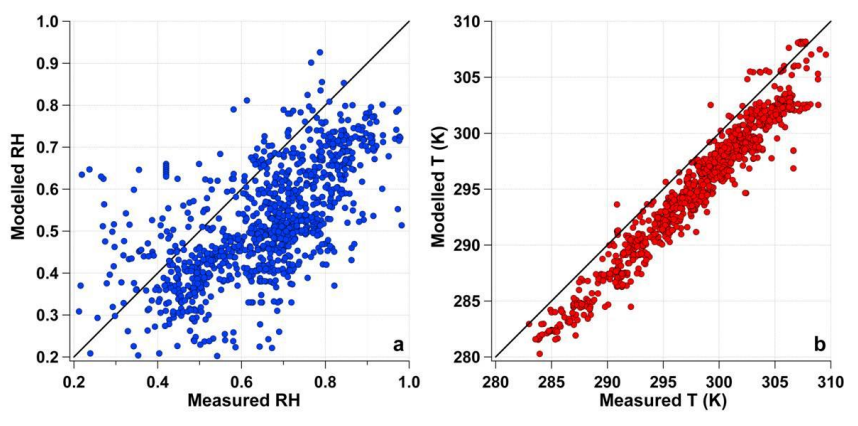

Fig. 10. Aircraft modelled vs. measured (a) RH (b) $T$. The black line is the $1: 1$ line.

FA values were positive. One of the reasons why measured FA values were lower aloft is because we had no $\mathrm{NH}_{3(\mathrm{~g})}$ instrument onboard the aircraft. In the absence of $\mathrm{NH}_{3(\mathrm{~g})}$ data we calculated TA by $\mathrm{TA} \equiv p \mathrm{NH}_{4}^{+}$, so measurements of FA from the aircraft are an underestimate, which further exacerbates the differences with respect to the model, which is already biased low for FA. We expect that the contribution of $\mathrm{NH}_{3 \text { (g) }}$ to TA (and hence FA) is less significant for the aircraft data than for Harrow because ammonia is emitted at the ground from agricultural and traffic sources; thus, we expect TA, and hence FA, values to be higher at the ground site. According to Fig. 7, the impact on $\mathrm{NO}_{3}^{-}$of a negative bias in FA ranges from negligible (under warm, dry conditions and low TN loadings) to significant (under cool, moist conditions with moderate to high $\mathrm{TN}$ ).

\subsection{Measured and modelled meteorological parameters}

Modelled values of relative humidity compared with measurements at Harrow were significantly lower across the entire spectrum of RH values (Fig. 9a). Only in a few instances was the modelled RH higher than the measurements, and this generally occurred in higher $\mathrm{RH}$ regimes $(\mathrm{RH}=0.70-0.90)$. The difference between modelled and measured $\mathrm{RH}$ for the most part ranged between -0.20 and -0.30 . The comparison between temperature data at Harrow (Fig. 9b) showed that the model was biased high at high temperatures and biased low at low temperatures. The difference between modelled and measured temperatures rarely exceeded $5 \mathrm{~K}$. The chemical maps in Fig. 7 show that the predictions of $p \mathrm{NO}_{3}^{-}$ are much more sensitive to temperature between $280 \mathrm{~K}$ and $290 \mathrm{~K}$ than between $300 \mathrm{~K}$ and $310 \mathrm{~K}$. The low bias at low temperatures likely contributes to the high bias in $p \mathrm{NO}_{3}^{-}$ seen on several days at Harrow (Fig. 2), which occur between 02:00 and 08:00 when the temperature was lowest.

Compared to measurements of relative humidity aboard the aircraft, modelled RH (Fig. 10a) values were significantly lower, much like at the ground site. The model was seldom biased high relative to the observations and the high bias was most pronounced at lower RH $(<0.60)$. The comparison 
Table 2. Comparison of measured $\mathrm{pNO}_{3}^{-}$mass loading with offline model runs using measured temperature and/or relative humidity at the ground and aloft during BAQS-Met. The column showing AURAMS data in this table is slightly different from Table 1, because it has been filtered to only include points for which measured $T$ and RH are available, which were needed to generate cases I-IV. Re-partitioning of AURAMS data was performed: (i) with original (AURAMS) met data (case I), (ii) with measured RH only (case II), (iii) with measured $T$ only (case III), and (iv) with measured RH and $T$ (case IV). For each case, the model is compared to the $\mathrm{AMS} p \mathrm{NO}_{3}^{-}$measurements. $\mathrm{MB}=$ mean bias, $\mathrm{ME}=$ mean error, $\mathrm{NMB}=$ normalized mean bias, $\mathrm{NME}=$ normalized mean error, $\mathrm{RMSE}=$ root mean square error, and $R=$ correlation coefficient.

\begin{tabular}{lrrrrr|rrrrr}
\hline & \multicolumn{4}{c}{ AIRCRAFT } & \multicolumn{4}{c}{ HARROW } \\
\cline { 2 - 10 } & AURAMS & case I & case II & case III & case IV & AURAMS & case I & case II & case III & case IV \\
\hline MB $\left(\mu \mathrm{g} \mathrm{m}^{-3}\right)$ & -0.22 & -0.25 & -0.21 & -0.27 & -0.25 & 0.01 & -0.05 & 0.12 & -0.12 & 0.08 \\
ME $\left(\mu \mathrm{g} \mathrm{m}^{-3}\right)$ & 0.30 & 0.30 & 0.29 & 0.31 & 0.29 & 0.63 & 0.61 & 0.71 & 0.56 & 0.68 \\
NMB $(\%)$ & -71.5 & -80.8 & -68.8 & -88.1 & -79.1 & 2.8 & -10.3 & 25.4 & -24.4 & 16.3 \\
NME $(\%)$ & 97.6 & 97.4 & 93.4 & 98.4 & 93.3 & 131 & 127 & 148 & 117 & 142 \\
RMSE $\left(\mu \mathrm{g} \mathrm{m}^{-3}\right)$ & 0.47 & 0.48 & 0.48 & 0.47 & 0.46 & 1.09 & 1.00 & 1.27 & 0.91 & 1.22 \\
$R$ & 0.12 & 0.09 & 0.20 & 0.06 & 0.18 & 0.29 & 0.28 & 0.32 & 0.25 & 0.30 \\
\hline
\end{tabular}

between measured and modelled temperature data (Fig. 10b) showed that the model was biased low (by $1-5 \mathrm{~K}$ ) over the entire study period. According to Fig. 7, the impact of biases in $\mathrm{RH}$ and $T$ on $p \mathrm{NO}_{3}^{-}$depends on the levels of TN and FA and is most important in the transition region.

\subsubsection{Sensitivity studies with meteorological variables}

In order to further investigate the impact of meteorological parameters on AURAMS's bias in $p \mathrm{NO}_{3}^{-}$, we performed a series of sensitivity tests in which we re-partitioned modelled $\mathrm{PM}_{1}$ data using ISORROPIA offline with (i) modelled meteorological data (case I), (ii) measured RH only (case II), (iii) measured $T$ only (case III), and (iv) measured $T$ and RH (case IV), with the results compiled in Table 2. These sensitivity tests were carried out both for the Harrow data and the aircraft data. Because of missing temperature and relative humidity measurements (more significant at Harrow than on aircraft), the "AURAMS" column in Table 2 refers to model output only from periods when meteorological measurements were available for use in the other cases. For case I, any differences compared to the original AURAMS data should only reflect differences in the partitioning calculated by the algorithms used in HETV and those in ISORROPIA v2.1, which was used in the offline re-partitioning analysis.

In terms of the chemical maps (Fig. 7), vertical shifts in the location of data brought about by changes in $T$ were more significant when the FA of the system was positive because regions of favourable and non-favourable nitrate formation were as little as $2-3 \mathrm{~K}$ apart for $T$ values observed during BAQS-Met (282-308 K). However, RH affects the entire chemical map and caused a large upward shift in the location of S-shaped transition curve - increasing RH from 0.65 to 0.90 is the equivalent of moving a point from Fig. $7 \mathrm{e}$ to Fig. 7f.

As shown in Table 2, re-partitioning of aircraft data with measured RH and $T$ had little effect on the overall metrics describing the predictions of $p \mathrm{NO}_{3}^{-}$. MB and RMSE values between measured and modelled $p \mathrm{NO}_{3}^{-}$showed very little variation between the cases. Re-partitioning with measured $T$ and RH (case IV) led to a slight improvement in correlation ( $R=0.18$, compared to $R=0.12)$ between modelled and measured nitrate. The slight improvement in correlation was the net result of the opposing effects of measured RH (case II, $R=0.20$ ) and $T$ (case III, $R=0.06$ ) on the modelled formation of $p \mathrm{NO}_{3}^{-}$. The limited effect of the substitution of measured $\mathrm{RH}$ and $T$ on the re-partitioning of the aircraft data is the result of the low FA values predicted by AURAMS during the campaign. As evident from Fig. 8a, approximately half of all modelled FA values were negative. In terms of the chemical maps, this means that modelled FA values were located in the upper left part of the map far from the transition curve where RH and $T$ have very little effect on formation of nitrate.

Compared to the aircraft data, re-partitioning of Harrow data with measured meteorological parameters had a more significant impact on predicted $p \mathrm{NO}_{3}^{-}$(Table 2). Repartitioning with measured $\mathrm{RH}$ led to an increase in predicted nitrate $\left(\mathrm{MB}=0.12 \mu \mathrm{g} \mathrm{m}^{-3}\right)$ and a better correlation $(R=0.32)$ with measured $p \mathrm{NO}_{3}^{-}$data. Re-partitioning with measured $T$ values, led to an overall decrease in predicted nitrate $\left(\mathrm{MB}=-0.12 \mu \mathrm{g} \mathrm{m}^{-3}\right)$ and in the correlation $(R=0.25)$ with measurements. The combined effect (case IV) of repartitioning was the same as for the aircraft data, which was an overall increase in predicted nitrate $\left(\mathrm{MB}=0.08 \mu \mathrm{g} \mathrm{m}^{-3}\right)$ and slight improvement in the correlation $(R=0.30)$. Even though the overall effect was an increase in predicted nitrate, for the most part, the increase occurred in instances when the FA of the system is positive and significant levels of nitrate already existed. This exacerbated the instances of $p \mathrm{NO}_{3}^{-}$ overprediction and led to an overall increase in RMSE from 1.09 to $1.22 \mu \mathrm{g} \mathrm{m}^{-3}$. 
These sensitivity studies demonstrate that the bias in modelled $\mathrm{RH}$ and $T$ contributes to some of the errors in $\mathrm{pNO}_{3}^{-}$ predicted by the AURAMS model during BAQS-Met. However, constraining $\mathrm{RH}$ and $T$ without also removing the bias in FA prevents significant improvements in the predictions. This simple offline re-partitioning approach does not fully account for the impact of inaccuracies in the meteorological parameters driving AURAMS, because gas/particle partitioning of TN (and TA) determines their lifetimes, which feeds back to the predictions of $p \mathrm{NO}_{3}^{-}$. For example, a low bias in $\mathrm{RH}$ is likely to produce a low bias in $\mathrm{pNO}_{3}^{-} / \mathrm{HNO}_{3(\mathrm{~g})}$, which will lead to a low bias in $\mathrm{TN}$ (because $\mathrm{HNO}_{3}(\mathrm{~g})$ deposits more quickly), further exacerbating the low bias in $\mathrm{pNO}_{3}^{-}$. From the chemical maps in Fig. 7, it is clear that in a sulphate-rich summertime atmosphere, the model output is most sensitive to temperature biases when $T<290 \mathrm{~K}$.

\section{Conclusions}

During the BAQS-Met campaign, A Unified Regional Airquality Modeling System (AURAMS) exhibited large biases in the prediction of $\mathrm{PM}_{1}$ nitrate. The agreement between model predictions and observations at the ground site $\left(\mathrm{M}_{\mathrm{obs}}\right.$ $=0.50 \mu \mathrm{g} \mathrm{m}^{-3} ; \mathrm{M}_{\mathrm{mod}}=0.58 \mu \mathrm{g} \mathrm{m}^{-3} ; \mathrm{RMSE}=1.27 \mu \mathrm{g} \mathrm{m}^{-3}$; and $R=0.39)$, was better than aloft $\left(\mathrm{M}_{\mathrm{obs}}=0.32 \mu \mathrm{g} \mathrm{m}^{-3}\right.$; $\left.\mathrm{M}_{\text {mod }}=0.09 \mu \mathrm{g} \mathrm{m}^{-3} ; \mathrm{RMSE}=0.48 \mu \mathrm{g} \mathrm{m}^{-3} ; R=0.12\right)$. In order to better understand the factors that limited AURAMS' ability to accurately predict $p \mathrm{NO}_{3}^{-}$during BAQS-Met, we generated a set of FA chemical maps that illustrated the relationship between the absolute amounts of TA, TS, TN, and meteorological variables $(\mathrm{RH}, T)$ in the formation of $p \mathrm{NO}_{3}^{-}$. From the histogram in Fig. 8a, we determined that for the aircraft data, AURAMS was biased low for $\mathrm{NNO}_{3}^{-}$because it was making predictions in the chemical map space where $p \mathrm{NO}_{3}^{-}$formation is not allowed due to negative FA. At Harrow, $p \mathrm{NO}_{3}^{-}$measurements ranged between 0.1 and $3 \mu \mathrm{g} \mathrm{m}^{-3}$, whereas the model predicted a wide range of values up to $8 \mu \mathrm{g} \mathrm{m}^{-3}$, with the most frequent prediction being zero. The underpredictions appear to be the result of a low bias in FA, whereas the overpredictions occur when FA is positive, but the temperature predictions are too low by several K. AURAMS was biased low for FA during the campaign because it was biased high for TS and/or biased low for TA. From the chemical FA maps, we concluded that at low temperatures and high relative humidity, the role of $\mathrm{FA}$ in $p \mathrm{NO}_{3}^{-}$formation becomes less important. Sensitivity tests with ISORROPIA using measured RH and $T$ showed that constraining meteorological inputs with measurements can only offer modest improvements in the predictions of $\mathrm{pNO}_{3}^{-}$if the FA values in the model remain biased. In this work, we developed a novel framework to examine the variables that affect the model's ability to accurately predict fine particulate nitrate. The results of our analysis are relevant to all regional air quality models and as such can help improve approaches to modelling regional PM pollution.
Acknowledgements. The authors would like to thank Ontario Ministry of Environment, Environment Canada, and Agriculture and Agri-Food Canada for support during BAQS-Met field campaign. The authors would also like to thank Jeffrey A. Geddes and Ilan Levy for their assistance with data analysis and G.J. Evans, C.-H. Jeong, and M.L. McGuire for providing us with meteorological data measurements from the Harrow site. We would also like to acknowledge the support of the pilots, technical crew and scientists from the National Research Council of Canada. M. Z. Markovic is grateful to Environment Canada for funding this analysis through Research Affiliate Position (RAP) programme.

Edited by: R. McLaren

\section{References}

Allan, J. D., Delia, A. E., Coe, H., Bower, K. N., Alfarra, M. R., Jimenez, J. L., Middlebrook, A. M., Drewnick, F., Onasch, T. B., Canagaratna, M. R., Jayne, J. T., and Worsnop, D. R.: A generalised method for the extraction of chemically resolved mass spectra from aerodyne aerosol mass spectrometer data, J. Aerosol Sci., 35, 909-922, 2004.

Amundson, N. R., Caboussat, A., He, J. W., Martynenko, A. V., Savarin, V. B., Seinfeld, J. H., and Yoo, K. Y.: A new inorganic atmospheric aerosol phase equilibrium model (UHAERO), Atmos. Chem. Phys., 6, 975-992, doi:10.5194/acp-6-975-2006, 2006.

Ansari, A. S. and Pandis, S. N.: An analysis of four models predicting the partitioning of semivolatile inorganic aerosol components, Aerosol Sci. Technol., 31, 129-153, 1999a.

Ansari, A. S., and Pandis, S. N.: Prediction of multicomponent inorganic atmospheric aerosol behavior, Atmos. Environ., 33, 745757, 1999b.

Bahreini, R., Dunlea, E. J., Matthew, B. M., Simons, C., Docherty, K. S., DeCarlo, P. F., Jimenez, J. L., Brock, C. A., and Middlebrook, A. M.: Design and operation of a pressure-controlled inlet for airborne sampling with an aerodynamic aerosol lens, Aerosol Sci. Technol., 42, 465-471, doi:10.1080/02786820802178514, 2008.

Bassett, M. and Seinfeld, J. H.: Atmospheric Equilibrium-Model of Sulfate and Nitrate Aerosols, Atmos. Environ., 17, 2237-2252, 1983.

Bassett, M. E. and Seinfeld, J. H.: Atmospheric Equilibrium-Model of Sulfate and Nitrate Aerosols .2. Particle-Size Analysis, Atmos. Environ., 18, 1163-1170, 1984.

Binkowski, F. S. and Roselle, S. J.: Models-3 community multiscale air quality (CMAQ) model aerosol component - 1 . Model description, J. Geophys. Res.-Atmos., 108(D6), 4183, doi:10.1029/2001JD001409, 2003.

Burnett, R. T., Brook, J., Dann, T., Delocla, C., Philips, O., Cakmak, S., Vincent, R., Goldberg, M. S., and Krewski, D.: Association between particulate- and gas-phase components of urban air pollution and daily mortality in eight Canadian cities, Inhal. Toxicol., 12, 15-39, 2000.

CEP: Carolina Environmental Program, Sparse Matrix Operator Kernel Emission (SMOKE) modelling system, University of North Carolina, Carolina Environmental Programs, Chapel Hill, NC, available at: http://www.smoke-model.org/index.cfm, 2003. Clegg, S. L.: Correction, J. Phys. Chem., 96, 6854-6854, 1992. 
Clegg, S. L. and Pitzer, K. S.: Thermodynamics of Multicomponent, Miscible, Ionic-Solutions - Generalized Equations for Symmetrical Electrolytes, J. Phys. Chem., 96, 3513-3520, 1992.

Clegg, S. L., Pitzer, K. S., and Brimblecombe, P.: Thermodynamics of Multicomponent, Miscible, Ionic-Solutions .2. Mixtures Including Unsymmetrical Electrolytes, J. Phys. Chem., 96, 94709479, 1992.

Clegg, S. L., Brimblecombe, P., and Wexler, A. S.: Thermodynamic model of the system $\mathrm{H}^{+}-\mathrm{NH}_{4}^{+}-\mathrm{SO}_{4}^{2-}-\mathrm{NO}_{3}^{-}-\mathrm{H}_{2} \mathrm{O}$ at tropospheric temperatures, J. Phys. Chem. A, 102, 2137-2154, 1998a.

Clegg, S. L., Brimblecombe, P., and Wexler, A. S.: Thermodynamic model of the system $\mathrm{H}^{+}-\mathrm{NH}_{4}^{+}-\mathrm{Na}^{+}-\mathrm{SO}_{4}^{2-}-\mathrm{NO}_{3}^{-}-\mathrm{Cl}^{-}-\mathrm{H}_{2} \mathrm{O}$ at 298.15 K, J. Phys. Chem. A, 102, 2155-2171, 1998 b.

Cote, J., Gravel, S., Methot, A., Patoine, A., Roch, M., and Staniforth, A.: The operational CMC-MRB Global Environmental Multiscale (GEM) model. Part I: Design considerations and formulation, Mon. Weather Rev., 126, 1373-1395, 1998.

Cross, E. S., Onasch, T. B., Canagaratna, M., Jayne, J. T., Kimmel, J., Yu, X.-Y., Alexander, M. L., Worsnop, D. R., and Davidovits, P.: Single particle characterization using a light scattering module coupled to a time-of-flight aerosol mass spectrometer, Atmos. Chem. Phys., 9, 7769-7793, doi:10.5194/acp-9-7769-2009, 2009.

Cruz, C. N., Dassios, K. G., and Pandis, S. N.: The effect of dioctyl phthalate films on the ammonium nitrate aerosol evaporation rate, Atmos. Environ., 34, 3897-3905, 2000.

Dassios, K. G. and Pandis, S. N.: The mass accommodation coefficient of ammonium nitrate aerosol, Atmos. Environ., 33, 29933003, 1999.

DeCarlo, P. F., Kimmel, J. R., Trimborn, A., Northway, M. J., Jayne, J. T., Aiken, A. C., Gonin, M., Fuhrer, K., Horvath, T., Docherty, K. S., Worsnop, D. R., and Jimenez, J. L.: Field-deployable, high-resolution, time-of-flight aerosol mass spectrometer, Anal. Chem., 78, 8281-8289, doi:10.1021/ac061249n, 2006.

Dockery, D. W.: Epidemiologic evidence of cardiovascular effects of particulate air pollution, Environ. Health Persp., 109, 483486, 2001.

Dominici, F., Peng, R. D., Bell, M. L., Pham, L., McDermott, A., Zeger, S. L., and Samet, J. M.: Fine particulate air pollution and hospital admission for cardiovascular and respiratory diseases, Jama-Journal of the American Medical Association, 295, 11271134, 2006.

Drewnick, F., Hings, S. S., DeCarlo, P., Jayne, J. T., Gonin, M., Fuhrer, K., Weimer, S., Jimenez, J. L., Demerjian, K. L., Borrmann, S., and Worsnop, D. R.: A new time-of-flight aerosol mass spectrometer (TOF-AMS) - Instrument description and first field deployment, Aerosol Sci. Technol., 39, 637-658, doI10.1080/02786820500182040, 2005.

Dunlea, E. J., DeCarlo, P. F., Aiken, A. C., Kimmel, J. R., Peltier, R. E., Weber, R. J., Tomlinson, J., Collins, D. R., Shinozuka, Y., McNaughton, C. S., Howell, S. G., Clarke, A. D., Emmons, L. K., Apel, E. C., Pfister, G. G., van Donkelaar, A., Martin, R. V., Millet, D. B., Heald, C. L., and Jimenez, J. L.: Evolution of Asian aerosols during transpacific transport in INTEX-B, Atmos. Chem. Phys., 9, 7257-7287, doi:10.5194/acp-9-7257-2009, 2009.

Ellis, R. A., Murphy, J. G., Pattey, E., van Haarlem, R., O’Brien, J. M., and Herndon, S. C.: Characterizing a Quantum Cascade Tunable Infrared Laser Differential Absorption Spectrometer (QC-
TILDAS) for measurements of atmospheric ammonia, Atmos. Meas. Tech., 3, 397-406, doi:10.5194/amt-3-397-2010, 2010.

Ellis, R. A., Murphy, J. G., Markovic, M. Z., VandenBoer, T. C., Makar, P. A., Brook, J., and Mihele, C.: The influence of gasparticle partitioning and surface-atmosphere exchange on ammonia during BAQS-Met, Atmos. Chem. Phys., 11, 133-145, doi:10.5194/acp-11-133-2011, 2011.

Finlayson-Pitts, B. J. and Pitts, J. N.: Chemistry of the Upper and Lower Atmosphere, Second ed., Academic Press, New York, 2000.

Fountoukis, C. and Nenes, A.: ISORROPIA II: a computationally efficient thermodynamic equilibrium model for $\mathrm{K}^{+}$ $\mathrm{Ca}^{2+}-\mathrm{Mg}^{2+}-\mathrm{NH}_{4}^{+}-\mathrm{Na}^{+}-\mathrm{SO}_{4}^{2-}-\mathrm{NO}_{3}^{-}-\mathrm{Cl}^{-}-\mathrm{H}_{2} \mathrm{O}$ aerosols, Atmos. Chem. Phys., 7, 4639-4659, doi:10.5194/acp-7-4639-2007, 2007.

Fountoukis, C., Nenes, A., Sullivan, A., Weber, R., Van Reken, T., Fischer, M., Matas, E., Moya, M., Farmer, D., and Cohen, R. C.: Thermodynamic characterization of Mexico City aerosol during MILAGRO 2006, Atmos. Chem. Phys., 9, 2141-2156, doi:10.5194/acp-9-2141-2009, 2009.

Gauderman, W. J., Avol, E., Gilliland, F., Vora, H., Thomas, D., Berhane, K., McConnell, R., Kuenzli, N., Lurmann, F., Rappaport, E., Margolis, H., Bates, D., and Peters, J.: The effect of air pollution on lung development from 10 to 18 years of age, New Engl. J. Med., 351, 1057-1067, 2004.

Gaydos, T. M., Pinder, R., Koo, B., Fahey, K. M., Yarwood, G., and Pandis, S. N.: Development and application of a threedimensional aerosol chemical transport model, PMCAMx, Atmos. Environ., 41, 2594-2611, 2007.

Gong, W. M., Dastoor, A. P., Bouchet, V. S., Gong, S. L., Makar, P. A., Moran, M. D., Pabla, B., Menard, S., Crevier, L. P., Cousineau, S., and Venkatesh, S.: Cloud processing of gases and aerosols in a regional air quality model (AURAMS), Atmos Res., 82, 248-275, doi:10.1016/j.atmosres.2005.10.012, 2006.

Hayden, K. L., Macdonald, A. M., Gong, W., Toom-Sauntry, D., Anlauf, K. G., Leithead, A., Li, S. M., Leaitch, W. R., and Noone, K.: Cloud processing of nitrate, J. Geophys. Res.Atmos., 113, D18201, doi:10.1029/2007JD009732, 2008.

Hayden, K. L., Sills, D. M. L., Brook, J. R., Li, S. M., Makar, P., Markovic, M. Z., Liu, P., Anlauf, K. G., O’Brien, J. M., Li, Q., and R., M.: The impact of lake breezes on trace gases and particles during the Border Air Quality and Meteorology Study (BAQS-Met), Atmos. Chem. Phys. Discuss., submitted, 2011.

Hennigan, C. J., Sullivan, A. P., Fountoukis, C. I., Nenes, A., Hecobian, A., Vargas, O., Peltier, R. E., Case Hanks, A. T., Huey, L. G., Lefer, B. L., Russell, A. G., and Weber, R. J.: On the volatility and production mechanisms of newly formed nitrate and water soluble organic aerosol in Mexico City, Atmos. Chem. Phys., 8, 3761-3768, doi:10.5194/acp-8-3761-2008, 2008.

Houyoux, M. R., Vukovich, J. M., Coats, C. J., Wheeler, N. J. M., and Kasibhatla, P. S.: Emission inventory development and processing for the Seasonal Model for Regional Air Quality (SMRAQ) project, J. Geophys. Res.-Atmos., 105(D7), 9079-9090, doi:10.1029/1999JD900975, 2000.

Jacob, D. J.: Introduction to Atmospheric Chemistry, Princeton University Press, Princeton, NJ, 1999.

Jacobson, M. Z.: Studying the effects of calcium and magnesium on size-distributed nitrate and ammonium with EQUISOLV II, Atmos. Environ., 33, 3635-3649, 1999. 
Jacobson, M. Z., Tabazadeh, A., and Turco, R. P.: Simulating equilibrium within aerosols and nonequilibrium between gases and aerosols, J. Geophys. Res.-Atmos., 101(D4) 9079-9091, doi:10.1029/96JD00348, 1996.

Karydis, V. A., Tsimpidi, A. P., and Pandis, S. N.: Evaluation of a three-dimensional chemical transport model (PMCAMx) in the eastern United States for all four seasons, J. Geophys. Res.Atmos., 112, D14211, doi:10.1029/2006JD007890, 2007.

Karydis, V. A., Tsimpidi, A. P., Fountoukis, C., Nenes, A., Zavala, M., Lei, W. F., Molina, L. T., and Pandis, S. N.: Simulating the fine and coarse inorganic particulate matter concentrations in a polluted megacity, Atmos. Environ., 44, 608-620, 2010.

Kim, Y. P. and Seinfeld, J. H.: Atmospheric Gas-Aerosol Equilibrium .3. Thermodynamics of Crustal Elements $\mathrm{Ca}^{2+}, \mathrm{K}^{+}$, and $\mathrm{Mg}^{2+}$, Aerosol Sci. Technol., 22, 93-110, 1995.

Kim, Y. P., Seinfeld, J. H., and Saxena, P.: Atmospheric GasAerosol Equilibrium .2. Analysis of Common Approximations and Activity-Coefficient Calculation Methods, Aerosol Sci. Technol., 19, 182-198, 1993a.

Kim, Y. P., Seinfeld, J. H., and Saxena, P.: Atmospheric Gas Aerosol Equilibrium .1. Thermodynamic Model, Aerosol Sci. Technol., 19, 157-181, 1993b.

Kleinman, L. I., Springston, S. R., Daum, P. H., Lee, Y.-N., Nunnermacker, L. J., Senum, G. I., Wang, J., Weinstein-Lloyd, J., Alexander, M. L., Hubbe, J., Ortega, J., Canagaratna, M. R., and Jayne, J.: The time evolution of aerosol composition over the Mexico City plateau, Atmos. Chem. Phys., 8, 1559-1575, doi:10.5194/acp-8-1559-2008, 2008.

Lurmann, F. W., Lloyd, A. C., and Atkinson, R.: A Chemical Mechanism for Use in Long-Range Transport Acid Deposition Computer Modeling, J. Geophys. Res.-Atmos., 91(D10), 905-936, doi:10.1029/JD091iD10p10905, 1986.

Makar, P. A., Bouchet, V. S., and Nenes, A.: Inorganic chemistry calculations using HETV-a vectorized solver for the $\mathrm{SO}_{4}^{2-}-\mathrm{NO}_{3}^{-}-\mathrm{NH}_{4}^{+}$system based on the ISORROPIA algorithms, Atmos. Environ., 37, 2279-2294, doi:10.1016/s13522310(03)00074-8, 2003.

Makar, P. A., Gong, W., Mooney, C., Zhang, J., Davignon, D., Samaali, M., Moran, M. D., He, H., Tarasick, D. W., Sills, D., and Chen, J.: Dynamic adjustment of climatological ozone boundary conditions for air-quality forecasts, Atmos. Chem. Phys., 10, 8997-9015, doi:10.5194/acp-10-8997-2010, 2010a.

Makar, P. A., Zhang, J., Gong, W., Stroud, C., Sills, D., Hayden, K. L., Brook, J., Levy, I., Mihele, C., Moran, M. D., Tarasick, D. W., He, H., and Plummer, D.: Mass tracking for chemical analysis: the causes of ozone formation in southern Ontario during BAQS-Met 2007, Atmos. Chem. Phys., 10, 11151-11173, doi:10.5194/acp-10-11151-2010, 2010b.

Mebust, M. R., Eder, B. K., Binkowski, F. S., and Roselle, S. J.: Models-3 community multiscale air quality (CMAQ) model aerosol component - 2. Model evaluation, J. Geophys. Res.Atmos., 108(D6), 4184, doi:10.1029/2001JD001410, 2003.

Meng, Z. Y. and Seinfeld, J. H.: Time scales to achieve atmospheric gas-aerosol equilibrium for volatile species, Atmos. Environ., 30, 2889-2900, 1996.

Meng, Z. Y., Seinfeld, J. H., Saxena, P., and Kim, Y. P.: Atmospheric Gas-Aerosol Equilibrium .4. Thermodynamics of Carbonates, Aerosol Sci. Technol., 23, 131-154, 1995.

Moya, M., Ansari, A. S., and Pandis, S. N.: Partitioning of nitrate and ammonium between the gas and particulate phases during the 1997 IMADA-AVER study in Mexico City, Atmos. Environ., 35, 1791-1804, 2001.

Mozurkewich, M.: The Dissociation-Constant of AmmoniumNitrate and Its Dependence on Temperature, Relative-Humidity and Particle-Size, Atmos. Environ. Part a-General Topics, 27, 261-270, 1993.

Nenes, A., Pandis, S. N., and Pilinis, C.: ISORROPIA: A new thermodynamic equilibrium model for multiphase multicomponent inorganic aerosols, Aquat. Geochem., 4, 123-152, 1998.

Nenes, A., Pandis, S. N., and Pilinis, C.: Continued development and testing of a new thermodynamic aerosol module for urban and regional air quality models, Atmos. Environ., 33, 15531560, 1999.

Nowak, J. B., Huey, L. G., Russell, A. G., Tian, D., Neuman, J. A., Orsini, D., Sjostedt, S. J., Sullivan, A. P., Tanner, D. J., Weber, R. J., Nenes, A., Edgerton, E., and Fehsenfeld, F. C.: Analysis of urban gas phase ammonia measurements from the 2002 Atlanta Aerosol Nucleation and Real-Time Characterization Experiment (ANARChE), J. Geophys. Res.-Atmos., 111, D17308, doi:10.1029/2006JD007113, 2006.

Oberdorster, G.: Pulmonary effects of inhaled ultrafine particles, Int. Arch. Occ. Env. Hea., 74, 1-8, 2001.

Peters, A., Dockery, D. W., Muller, J. E., and Mittleman, M. A.: Increased particulate air pollution and the triggering of myocardial infarction, Circulation, 103, 2810-2815, 2001.

Pilinis, C. and Seinfeld, J. H.: Continued Development of a General Equilibrium-Model for Inorganic Multicomponent Atmospheric Aerosols, Atmos. Environ., 21, 2453-2466, 1987.

Pinder, R. W., Adams, P. J., and Pandis, S. N.: Ammonia emission controls as a cost-effective strategy for reducing atmospheric particulate matter in the eastern United States, Environ. Sci. Tech., 41, 380-386, 2007.

Pope, C. A., Burnett, R. T., Thun, M. J., Calle, E. E., Krewski, D., Ito, K., and Thurston, G. D.: Lung cancer, cardiopulmonary mortality, and long-term exposure to fine particulate air pollution, Jama-J Am. Med. Assoc., 287, 1132-1141, 2002.

San Martini, F. M., Dunlea, E. J., Volkamer, R., Onasch, T. B., Jayne, J. T., Canagaratna, M. R., Worsnop, D. R., Kolb, C. E., Shorter, J. H., Herndon, S. C., Zahniser, M. S., Salcedo, D., Dzepina, K., Jimenez, J. L., Ortega, J. M., Johnson, K. S., McRae, G. J., Molina, L. T., and Molina, M. J.: Implementation of a Markov Chain Monte Carlo method to inorganic aerosol modeling of observations from the MCMA-2003 campaign - Part II: Model application to the CENICA, Pedregal and Santa Ana sites, Atmos. Chem. Phys., 6, 4889-4904, doi:10.5194/acp-64889-2006, 2006.

Saxena, P., Hudischewskyj, A. B., Seigneur, C., and Seinfeld, J. H.: A Comparative-Study of Equilibrium Approaches to the Chemical Characterization of Secondary Aerosols, Atmos. Environ., 20, 1471-1483, 1986.

Seinfeld, J. H. and Pandis, S. N. : Atmospheric Chemistry and Physics, John Wiley \& Sons, New York, 1996.

Slowik, J. G., Brook, J., Chang, R. Y.-W., Evans, G. J., Hayden, K., Jeong, C.-H., Li, S.-M., Liggio, J., Liu, P. S. K., McGuire, M., Mihele, C., Sjostedt, S., Vlasenko, A., and Abbatt, J. P. D.: Photochemical processing of organic aerosol at nearby continental sites: contrast between urban plumes and regional aerosol, Atmos. Chem. Phys. Discuss., 10, 24993-25031, 
doi:10.5194/acpd-10-24993-2010, 2010.

Stelson, A. W. and Seinfeld, J. H.: Thermodynamic Prediction of the Water Activity, $\mathrm{NH}_{4} \mathrm{NO}_{3}$ Dissociation-Constant, Density and Refractive-Index for the $\mathrm{NH}_{4} \mathrm{NO}_{3}-\left(\mathrm{NH}_{4}\right)_{2} \mathrm{SO}_{4}-\mathrm{H}_{2} \mathrm{O}$ System at $25^{\circ} \mathrm{C}$, Atmos. Environ., 16, 2507-2514, 1982.

Wexler, A. S. and Seinfeld, J. H.: The Distribution of AmmoniumSalts among a Size and Composition Dispersed Aerosol, Atmos. Environ. Part a-General Topics, 24, 1231-1246, 1990.

Wexler, A. S. and Seinfeld, J. H.: 2nd-Generation Inorganic Aerosol Model, Atmos. Environ. Part a-General Topics, 25, 2731-2748, 1991.

Wexler, A. S. and Clegg, S. L.: Atmospheric aerosol models for systems including the ions $\mathrm{H}^{+}, \mathrm{NH}_{4}^{+}, \mathrm{Na}^{+}, \mathrm{SO}_{4}^{2-}, \mathrm{NO}_{3}^{-}, \mathrm{Cl}^{-}$, $\mathrm{Br}^{-}$, and $\mathrm{H}_{2} \mathrm{O}$, J.of Geophys. Res.-Atmos., 107, D14, 4207, doi:10.1029/2001jd000451, 2002.

Young, T. R. and Boris, J. P.: Numerical Technique for Solving Stiff Ordinary Differential-Equations Associated with ChemicalKinetics of Reactive-Flow Problems, J. Phys. Chem., 81, 24242427, 1977.

Yu, S. C., Dennis, R., Roselle, S., Nenes, A., Walker, J., Eder, B., Schere, K., Swall, J., and Robarge, W.: An assessment of the ability of three-dimensional air quality models with current thermodynamic equilibrium models to predict aerosol $\mathrm{NO}_{3}^{-}, \mathrm{J}$. Geophys. Res.-Atmos., 110, D0713, doi:10.1029/2004jd004718, 2005.
Zaveri, R. A., Easter, R. C., and Peters, L. K.: A computationally efficient multicomponent equilibrium solver for aerosols (MESA), J. Geophys. Res.-Atmos., 110, D24203, doi:10.1029/2004JD005618, 2005.

Zhang, Y., Seigneur, C., Seinfeld, J. H., Jacobson, M., Clegg, S. L., and Binkowski, F. S.: A comparative review of inorganic aerosol thermodynamic equilibrium modules: similarities, differences, and their likely causes, Atmos. Environ., 34, 117-137, 2000.

Zhang, L. M., Moran, M. D., Makar, P. A., Brook, J. R., and Gong, S. L.: Modelling gaseous dry deposition in AURAMS: a unified regional air-quality modelling system, Atmos. Environ., 36, 537560, 2002.

Zhang, J., Chameides, W. L., Weber, R., Cass, G., Orsini, D., Edgerton, E., Jongejan, P., and Slanina, J.: An evaluation of the thermodynamic equilibrium assumption for fine particulate composition: Nitrate and ammonium during the 1999 Atlanta Supersite Experiment, J. Geophys. Res.-Atmos., 108(D7), 8414, doi:10.1029/2001JD001592, 2003. 